OPEN ACCESS

Edited by:

Andrew D. Powell,

University of Birmingham, UK

Reviewed by:

Gillian Grafton,

University of Birmingham, UK

Thomas Freret,

University of Caen, France

*Correspondence:

Alfredo Meneses,

Departamento de Farmacobiología,

Centro de Investigación y de Estudios

Avanzados del Instituto Politécnico

Nacional, Tenorios 235, Granjas

Coapa, Mexico City 14330, Mexico ameneses@msn.com

Specialty section

This article was submitted to

Neuropharmacology,

a section of the journal

Frontiers in Pharmacology

Received: 17 April 2015

Accepted: 29 June 2015

Published: 21 July 2015

Citation:

Meneses A (2015) Serotonin, neural markers, and memory.

Front. Pharmacol. 6:143.

doi: 10.3389/fphar.2015.00143

\section{Serotonin, neural markers, and memory}

\author{
Alfredo Meneses* \\ Departamento de Farmacobiología, Centro de Investigación y de Estudios Avanzados del Instituto Politécnico Nacional, \\ Mexico City, Mexico
}

Diverse neuropsychiatric disorders present dysfunctional memory and no effective treatment exits for them; likely as result of the absence of neural markers associated to memory. Neurotransmitter systems and signaling pathways have been implicated in memory and dysfunctional memory; however, their role is poorly understood. Hence, neural markers and cerebral functions and dysfunctions are revised. To our knowledge no previous systematic works have been published addressing these issues. The interactions among behavioral tasks, control groups and molecular changes and/or pharmacological effects are mentioned. Neurotransmitter receptors and signaling pathways, during normal and abnormally functioning memory with an emphasis on the behavioral aspects of memory are revised. With focus on serotonin, since as it is a well characterized neurotransmitter, with multiple pharmacological tools, and well characterized downstream signaling in mammals' species. $5-\mathrm{HT}_{1 \mathrm{~A}}, 5-\mathrm{HT}_{4}, 5-\mathrm{HT}_{5}$, $5-\mathrm{HT}_{6}$, and $5-\mathrm{HT}_{7}$ receptors as well as SERT (serotonin transporter) seem to be useful neural markers and/or therapeutic targets. Certainly, if the mentioned evidence is replicated, then the translatability from preclinical and clinical studies to neural changes might be confirmed. Hypothesis and theories might provide appropriate limits and perspectives of evidence.

Keywords: memory, drugs, neural markers

\section{Introduction}

It should noted that while, memory formation and forgetting are functions of the brain (e.g., Fioravanti and Di Cesare, 1992; Wagner and Davachi, 2001; Wixted, 2004; Mansuy, 2005; Hardt et al., 2013; Hupbach, 2013; Callaghan et al., 2014; Li et al., 2015a); in contrast, diverse neuropsychiatric disorders present dysfunctional memory (Meyer-Lindenberg et al., 2012; Millan et al., 2012, 2014). AD is popular brain alteration presenting memory deficits and dementia and the leading cause of dementia, and a major public health priority; but dysfunctional memory is observed in other age-related neurodegenerative disorders, schizophrenia, post-traumatic stress disorder, strokes, etc. (Millan et al., 2014; Hashimoto, 2015). Certainly, no effective treatment for dysfunctional memory exists (e.g., Millan et al., 2012, 2014; Sun et al., 2015); likely due to the absence of neural markers associated to memory. Hence, memory, amnesia, forgetting (e.g., Tellez et al., 2012b) and AD (e.g., McConathy and Sheline, 2015; Muenchhoff et al., 2015; also Scarr et al., 2015) as well as mild cognitive impairment (MCI) (Eshkoor et al., 2015) require neural markers.

Certainly, $\mathrm{AD}$ is a very complex neuropsychiatric disorder, where memory becomes progressively dysfunctional (e.g., Solodkin and van Hoesen, 1997; Rodríguez et al., 2012) resulting in amnesia and dementia. In contrast, forgetting is unintentional process characterized as a failure 
to remember information or a rather strategic function of the brain that helps to reduce interference in the processing or retrieval of relevant information (Ludowiq et al., 2010). Likewise, forgetting as a physiological phenomenon occurs all the time (see McGaugh, 2013; see also Davis, 2010; Berry et al., 2012; Hardt et al., 2013; Kaku et al., 2013; Li and Richardson, 2013; Papenberg et al., 2013). However, the pharmacological and neuroanatomical bases of forgetting or memory have been little explored and as diverse neuropsychiatric disorders present dysfunctional memory, we are aiming potential neural markers.

For instance, phrasing neural markers and brain functions in PubMed (May 7, 21 and 29 or June 2, 2015) yield 318 or 319 (including 50 review papers) publications. Hence, herein, aiming clues about mapping neural markers link to cerebral functions and dysfunctions. Mainly memory formation, dysfunctional memory, and as forgetting, which has been little explored respect to neural markers. In spite of promissory findings, to our knowledge, no previous systematic works have been published addressing these issues. It should be noted that of the revised papers, several are rich in backgrounds and perspectives.

Examples illustrating the interaction among behavioral tasks (Box 1), control groups and molecular changes and/or pharmacological effects are mentioned in the following lines. Importantly, behavioral parameters, drug-treatment and cognitive processes interact in mammals (see below) and invertebrate species (e.g., Chen et al., 2014). Particularly the role of serotonin in memory: interactions with neurotransmitters and downstream signaling might be useful (e.g., Seyedabadi et al., 2014; Eskenazi et al., 2015). Although the focus herein are adult mammal animals; notwithstanding, important recent advances in invertebrate species, include Monje et al. (2013) reporting that flotillin-1 is an evolutionary-conserved memory-related protein up-regulated in implicit and explicit learning paradigms; thus, translational approach-from invertebrates to rodents-led to the identification of flotillin-1 as an evolutionary-conserved memory-related protein.

Actually, serotonin has pharmacological tools and well characterized downstream signaling in mammals' species (e.g., Marin et al., 2012; Borroto-Escuela et al., 2015; McCorvy and Roth, 2015); then serotonin and other neural markers are used for studying cerebral functions and dysfunctions (e.g., Tomie et al., 2003; Wellman et al., 2007; Cavallaro, 2008; Marcos et al., 2008; Da Silva Costa-Aze et al., 2012; Ménard and Quirion, 2012; Reichel et al., 2012; Rodríguez et al., 2012; Woods et al., 2012; Haahr et al., 2013; Alabdali et al., 2014; Freret et al., 2014; Kitamura et al., 2014; Kondo et al., 2014; Lecoutey et al., 2014; Leger et al., 2014; Seyedabadi et al., 2014; Leiser et al., 2015; Suzuki and Lucas, 2015; Westrich et al., 2015; Zilles et al., 2015). Evidence is organized according with 5-HT markers (i.e., receptors and transporter) but markers of other neurotransmission systems are included. Importantly, using well-established 5-HT neural markers (Blenau and Baumann, 2015; Lau et al., 2015; Müller and Homberg, 2015) might provide insights about known and novel markers and therapeutic targets. Müller and Homberg (2015) are providing an excellent analysis regarding 5-HT markers, drug use and addiction.

\section{Memory Tasks and Molecular Changes}

\section{Memory Decline across Aging}

Ménard and Quirion (2012) using the Morris Water Maze (MWM) task, distinguish aged rats in two groups-memoryimpaired (AI) and memory-unimpaired (AU) relative to 6months old adult animals. Dysfunctional memory was associated to increased metabotropic glutamate receptors 5 (mGluR5) in hippocampal post-synaptic densities (PSD) (Table 1); Ménard and Quirion (2012) conclude that in successful cognitive aging (i.e., AU animals) present a critical role for mGluR5, Homer 1 proteins and downstream signaling pathways. Certainly, in terms of signaling respect to cognition-enhancing drug targets, insights are emerging (e.g., Seyedabadi et al., 2014; Gyurko et al., 2015; Ménard et al., 2015; Sun et al., 2015).

\section{Autism: Neuro-inflammation and Neurotransmission Impairment}

Although, Alabdali et al. (2014) did find that serotonin or dopamine in platelet-free plasma not correlated with social and cognitive dysfunction. It should be noted that serotonin has multiple markers (see below). And, several neurochemical parameters might show sensitivity and specificity; thus contributing to earlier and more accurate diagnosis of dysfunctional memory in disease such autism, $\mathrm{AD}$, and the identification of effective treatments (e.g., Sheline et al., 2014a,b; Strac et al., 2015).

\section{5-HT Systems}

As already mentioned, serotonin (5-hydroxytryptamine, 5-HT) is one of the neurotransmitter well characterized in mammal species (e.g., Hoyer et al., 1994; Saulin et al., 2012; BorrotoEscuela et al., 2015; McCorvy and Roth, 2015), it has multiple

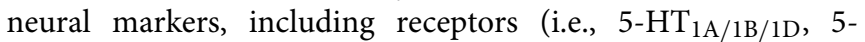

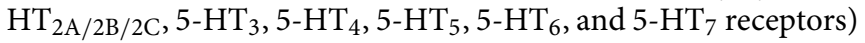
and transporter (named SERT) as well as volume transmission. These 5-HT markers are present in brain areas involved in memory (e.g., Buhot et al., 2003a,b; Puig and Gulledge, 2011; Rodríguez et al., 2012; Barlow et al., 2015; Leiser et al., 2015), sentence compression (Zilles et al., 2015) and drug addiction (Müller and Homberg, 2015).

\section{Serotonergic Gene Regulation during Learning and Memory}

In an elegant work, Cavallaro (2008) using DNA microarrays analyzed hippocampal 5-HT receptors in two behavioral memory tasks and different times (Table 2); observing differential expressions in 12 receptors (Htr1a, Htr1b, Htr1d, Htr1f, Htr2a, Htr2c, Htr3a, Htr4, Htr5a, Htr5b, Htr6, and Htr7). At least Htr2c, Htr3a and Htr6 receptors had significant changes relative to swimming control animals and water maze trained animals. $\mathrm{Htr} 2 \mathrm{c}$ expression was reduced at $1 \mathrm{~h}$ and increased at $24 \mathrm{~h}$ following training. Htr3a-mRNA was increased at $24 \mathrm{~h}$, whereas Htr6 was decreased at $6 \mathrm{~h}$; as observed in autoshaping (see below). In passive avoidance task, three 5-HT receptors showed changes in expression respect to naive and trained animals (i.e., conditioned animals, CA). Indeed, the expression of Htr3a was 
increased, whereas those of Htrlb and Htr4 were decreased. Certainly, expression of 5-HT receptors were also observed in control groups subjected to physical activity and mild stress (naive vs. swimming controls in the water maze; naive vs. CSTA and USTA in passive avoidance); notwithstanding, memory consolidation produced different magnitudes (e.g., Htr $2 \mathrm{c}$ in the water maze) often opposite trends than in control animals (e.g., $\mathrm{Htr} 3 \mathrm{a}$ in both water maze and passive avoidance). Producing cumulative patterns of gene expression, associated to time and 5-HT subtype receptor (see Cavallaro, 2008). Importantly, apparently water maze memory requires slight $5-\mathrm{HT}_{7}$ receptor expression within 1-h; and passive avoidance memory involves expression of $5-\mathrm{HT}_{1 \mathrm{~A}-1 \mathrm{~F}}, 5-\mathrm{HT}_{2 \mathrm{~A}}$, and $5-\mathrm{HT}_{5 \mathrm{~A}}$ receptors. Of course, remaining to determine if the suppression of the other 5HT receptors is necessary. Certainly, the molecular requirements differ between water maze and passive avoidance.

TABLE 1 | Memory task and molecular changes: unimpaired vs. impaired aging vs. adult rats.

\begin{tabular}{lll}
\hline $\begin{array}{l}\text { Function/ } \\
\text { dysfunction }\end{array}$ & Major findings & References \\
\hline $\begin{array}{l}\text { Following MWM } \\
\text { training }\end{array}$ & Brain area: hippocampal (CA1) & $\begin{array}{l}\text { Ménard and Quirion, } \\
\text { Groups }\end{array}$ \\
Al & \\
& -Al dysfunctional memory, $\uparrow$ in \\
& hippocampal (CA1) mGluR5 in PSD \\
& -Hippocampal up-regulated Homer 1a \\
& and 1b/c levels PSD \\
\hline AU & -AU had enhanced mGluR5 as well as \\
& Homer 1b/c stainings. \\
& - AU had higher PKCc, ERK, p70S6K, \\
& mTOR, and CREB activation. \\
& - AU higher expression of immediate \\
& early gene Arc/Arg3.1.
\end{tabular}

MWM, Morris Water Maze; Aging AU, memory unimpaired; aging impaired memory (IM), $P S D$, post-synaptic densities.
Notably, Zaldivar and Krichmar (2013) observe in behaviorally naïve (i.e., untrained) animals, neurotransmitters changing including 5-HT receptors expression in areas regarded to neuromodulation or memory (amygdala); revealing connectivity and receptor localization, and patterns of expression among neurotransmission systems, receptors and brain areas.

\section{5-HT ${ }_{1 A}$ Receptor}

Although $5-\mathrm{HT}_{1 \mathrm{~A}}$ receptor may serve as a biomarker for cognitive functioning and target for treatment of cognitive impairment; notwithstanding hitherto evidence remains sparse and inconsistent (Borg, 2008; Borg et al., 2009). Certainly, the situation is changing; e.g., Yoshimi et al. (2014) report that brexpiprazole, presents serotonin-dopamine activity, and $5-\mathrm{HT}_{1 \mathrm{~A}}$ receptor partial agonism, attenuates phencyclidineinduced cognitive deficits; an effect blocked by the selective $5-\mathrm{HT}_{1 \mathrm{~A}}$ receptor antagonist WAY-100,635 (which alone has no effect). Yoshimi et al. (2014) conclude that brexpiprazole could ameliorate cognitive deficits in schizophrenia and other neuropsychiatric diseases. Contrasting findings exist regarding the 5- $\mathrm{HT}_{1 \mathrm{~A}}$ partial agonists (e.g., buspirone), which alone impair memory in normal subjects (Meneses, 1999) but some of them (e.g., tandospirone) might be useful in the treatment of schizophrenia pathophysiology (Sumiyoshi et al., 2008). And, as tandospirone (e.g., Baba et al., 2015) also has anti-amnesic effects or facilitate performance in difficult memory tasks; hence, $5-\mathrm{HT}_{1 \mathrm{~A}}$ partial agonists might be useful in the treatment of dysfunctional memory.

Certainly, while if 5- $\mathrm{HT}_{1 \mathrm{~A}}$ receptor agonists, partial agonists, or antagonists might be used for memory alterations (e.g., Meneses and Perez-Garcia, 2007; Pittalà et al., 2015); functional selectivity or biased agonism is revealing important insights regarding $5-\mathrm{HT}_{1 \mathrm{~A}}$ and $5-\mathrm{HT}_{3 \mathrm{~A}}$ receptors (e.g., Vardy and Kenakin, 2014; McCorvy and Roth, 2015). For instance, van Goethem et al. (2015) study "biased," 5- $\mathrm{HT}_{1 \mathrm{~A}}$ receptor agonists in a novel object pattern separation task (relative to episodic memory); showing that by preferentially activating post-synaptic

TABLE 2 | 5-HT 1 A receptor.

\begin{tabular}{|c|c|c|c|c|}
\hline Function/dysfunction & Findings: & & & \\
\hline \multirow[t]{3}{*}{ Memory tasks } & Water maze & Passive avoidance & Fear conditioning ${ }^{h, i}$ & $\begin{array}{l}\text { Pavlovian } \\
\text { autoshaping }\end{array}$ \\
\hline & & & $\begin{array}{l}\text { genetic variability within } \\
5-\mathrm{HTR}_{1 \mathrm{~A}} \text { (rs6295) }\end{array}$ & $\begin{array}{l}\text { Pavlovian/Instrumental } \\
\text { autoshapingb,d }\end{array}$ \\
\hline & memory impairment and variations in expression ${ }^{e}$ & expression ${ }^{\mathrm{C}}$ & modulation of expression ${ }^{\mathrm{i}}$ & expression \\
\hline
\end{tabular}

recovery from dissociative

increase of $5-\mathrm{HT}_{1}$ A receptor in cortical regions 9

amnesia

object-location associations lower right than left hippocampal binding potential is

related to better memory performance ${ }^{j}$

Morris water maze memory expression ${ }^{f}$

retrieval

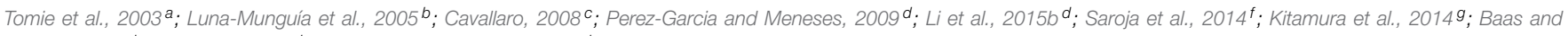
Heitland, 2014 ${ }^{h}$; Sase et al., 2015i ; Glikmann-Johnston et al., 2015j. 
TABLE 3 | 5-HT $1 \mathrm{~B}$ receptor.

\begin{tabular}{|c|c|c|}
\hline Function/dysfunction & Findings & References \\
\hline \multicolumn{3}{|l|}{ Following } \\
\hline \multicolumn{3}{|l|}{ Groups } \\
\hline 5- $\mathrm{HT}_{1 \mathrm{~B}}$ receptor $\mathrm{KO}$ & $\begin{array}{l}\text { Exhibit a task-dependent selective learning facilitation; indeed, selective facilitation/impairment } \\
\text { depending on the cognitive demand and/or age-related decline in spatial learning (water maze) abilities }\end{array}$ & $\begin{array}{l}\text { Buhot et al., 2003a,b; Wolff } \\
\text { et al., } 2003\end{array}$ \\
\hline Aggressive social model & High 5-HT1B receptor density in the BLA to predict high levels of aggression in observer rats & Suzuki and Lucas, 2015 \\
\hline Expression & $\begin{array}{l}\text { Positive correlations in control subjects between creative ability and average } 5-\mathrm{HT}_{1 \mathrm{~B}} \text { receptor availability } \\
\text { in gray matter }\end{array}$ & Varrone et al., 2015 \\
\hline
\end{tabular}

$B L A$, basolateral amygdala.

$5-\mathrm{HT}_{1 \mathrm{~A}}$ heteroreceptors, or raphe-nuclei autoreceptors are potential novel molecular targets for improving memory. Likewise, Stroth et al. (2015) report that arylpiperazine ligands of $5-\mathrm{HT}_{1 \mathrm{~A}}$ receptor preferentially affect cAMP signaling vs. $\beta$ arrestin-2 recruitment; proposing the development of signaling pathway-selective drugs targeting this receptor.

Notably, recovery from dissociative amnesia increases cortical 5- $\mathrm{HT}_{1 \mathrm{~A}}$ receptor (Kitamura et al., 2014; Table 3). Likewise, memory in autoshaping task (see Box 2) also increases $5-\mathrm{HT}_{1 \mathrm{~A}}$ receptor expression in 14 brain areas, but decrements in 7 and no changes in 12 (Table 3); suggesting that upregulated, down-regulated, and "silence" $5-\mathrm{HT}_{1 \mathrm{~A}}$ receptor in brain areas form part of neural circuits engaged in memory formation; thus demonstrating a high degree of specificity and memory mapping.

Importantly, Glikmann-Johnston et al. (2015) report that hippocampal human asymmetry in $5-\mathrm{HT}_{1 \mathrm{~A}}$ receptor expression (using $\left[{ }^{18} \mathrm{~F}\right] \mathrm{MPPF}$ binding), accompanies memory for objectlocation associations; lower right than left hippocampal binding potential is related to better memory performance (Table 2). Aubert et al. (2013) also report that the dual 5- $\mathrm{HT}_{1 \mathrm{~A} / 7}$ receptor agonist 8-OH-DPAT increased transcription of adenylate cyclase 1 in the hippocampus (CA1), suggesting that memory function could play a role in altered pairmate interaction dynamics; and these changes might be caused by $8-\mathrm{OH}$-DPAT-induced up- or down-regulation of $5-\mathrm{HT}_{1 \mathrm{~A}}$ and $5-\mathrm{HT}_{7}$ receptor in the medial prefrontal cortex and in the hippocampus (CA1), respectively; and according with Aubert et al. (2013); and such as hypothesis is supported by rodent studies that implicate $5-\mathrm{HT}_{7}$ function in contextual learning and memory consolidation.

On the other hand, genetic variability within $5-\mathrm{HT}_{1 \mathrm{~A}}$ receptor (rs6295) is associated with contextual fear independent (Table 3) (Baas and Heitland, 2014). Likewise, Weber et al. (2015) report that conditional inactivation of the GLUA1-encoding Grial gene selectively in 5-HT neurons of adult mice (i.e., Grial 5-HT-/- mice) exhibited a distinct anxiety phenotype but showed no alterations in locomotion, depression-like behavior, or learning and memory. Importantly, contextual fear task increases hippocampal AMPA-, GluN1- and 5- $\mathrm{HT}_{1 \mathrm{~A}}$ - containing receptor complexes (Sase et al., 2015) (Table 3). In addition, Saroja et al. (2014) studied spatial memory retrieval and hippocampal monoamine receptor (MAR) complexes (including 5- $\mathrm{HT}_{1 \mathrm{~A}}$ and $5-\mathrm{HT}_{7}$ receptors, and dopamine $\mathrm{D} 1$ and $\mathrm{D} 2$ receptors and colocalizations) in mice of 3-12 and 18 months. D1, D2, and $5-\mathrm{HT}_{7}$ containing receptor complex levels were decreasing with age while $5-\mathrm{HT}_{1 \mathrm{~A}}$ receptor-containing complex was increased. In addition, the time spent in the target quadrant (i.e., memory retrieval) correlated with $\mathrm{D} 1,5-\mathrm{HT}_{7}$, and $5-\mathrm{HT}_{1 \mathrm{~A}}$ receptors complex expression. Saroja et al. (2014) conclude that individual monoamine receptors are linked to spatial memory retrieval and are modulated by age. This same group (Subramaniyan et al., 2015) reports that the receptor complex levels containing hippocampal GluN1 and GluN2A of NMDARs, GluA1 and GluA2 of AMPA receptors, nAch7 and the D1A dopamine receptors were elevated during spatial learning, whilst levels of GluA3 and 5- $\mathrm{HT}_{1 \mathrm{~A}}$ receptor containing complexes were reduced. Thus, supporting that $5-\mathrm{HT}_{1 \mathrm{~A}}$ receptor is useful neurobiological marker of memory.

\section{Pavlovian Autoshaping: 5- $\mathrm{HT}_{1 \mathrm{~A}}$ and $5-\mathrm{HT}_{2}$ Receptors (Binding Sites)}

Interestingly, Tomie et al. (2003), studied the effects of experience with Pavlovian autoshaping procedures (Box 2) on lever-press conditioned response (CR) performance and ${ }^{3} \mathrm{H}-8-\mathrm{OH}-\mathrm{DPAT}$ labeled binding of $5-\mathrm{HT}_{1 \mathrm{~A}}$ and probably $5-\mathrm{HT}_{7}$ (it should be noted that this drug has affinity for $5-\mathrm{HT}_{7}$, see below; Table 3); as well as ${ }^{125} \mathrm{I}$-LSD-labeled binding of $5-\mathrm{HT}_{2 \mathrm{~A}}$ receptors were evaluated in four groups of rats. The groups (Paired High CR and Paired Low CR) received Pavlovian autoshaping procedures wherein the presentation of a lever (conditioned stimulus, CS) was followed by the response-independent presentation of food (unconditioned stimulus, US). Group Paired High CR showed more rapid CR acquisition and higher asymptotic levels of lever-press autoshaping CR performance relative to Group Low CR. Group Omission received autoshaping with an omission contingency, such that performing the lever-press autoshaping CR resulted in the cancelation the food US, while Group Random received presentations of lever CS and food US randomly with respect to one another. Though Groups Omission and Random did not differ in lever-press autoshaping CR performance, Group Omission showed significantly lower levels of $5-\mathrm{HT}_{1 \mathrm{~A}}$ binding in post-synaptic areas (frontal cortex, septum, caudate putamen), as well as significantly higher plasma corticosterone levels than Group Random. In addition, Group Random showed higher levels of $5-\mathrm{HT}_{1 \mathrm{~A}}$ binding in pre-synaptic somatodendritic autoreceptors on dorsal raphe nucleus relative 
to the other three groups. Autoradiographic analysis of $5-\mathrm{HT}_{2 \mathrm{~A}}$ receptor binding revealed no significant differences between Groups Paired High CR and Paired Low CR or between Groups Omission and Random in any brain regions. Notably, although extensive Pavlovian autoshaping training (Tomie et al., 2003) failed to produce any correlation between $5-\mathrm{HT}_{1 \mathrm{~A}}$ or $5-\mathrm{HT}_{2 \mathrm{~A}}$ receptor expression and $\mathrm{CR}$; however, regardless the number of CR, Tomie et al. (2003) demonstrated correlation between both receptors expression and paired CS-US presentations. These data are also indicating that the neuroanatomical, neurochemical, and behavioral basis of Pavlovian and Pavlovian/Instrumental Autoshaping (P/I-A) are different (see Box 2). Although the latter could be considered as an instance of system processing styles (i.e., S-S, S-R, and stimulus-reinforcer [S-Rf] learning; see White and McDonald, 2002); nevertheless, the association of CR and 5-HT markers (Tomie et al., 2003) is replicated (Pérez-García et al., 2006; Pérez-García and Meneses, 2008). Notably, similar associations are observed in the Morris Water Maze and passive avoidance tasks (Cavallaro, 2008). Hence, the evidence supports the notion that $5-\mathrm{HT}_{1 \mathrm{~A}}$ receptor provides diverse neurobiological markers, pharmacological and genetic tools that have been used to investigate a variety of functions and dysfunctions (for references Meneses and Liy-Salmeron, 2012). Likewise, $5-\mathrm{HT}_{1 \mathrm{~A}}$ receptor also is therapeutic target, it seems to be useful for detecting functional and dysfunctional memory, and co-expression with other neurotransmission systems and serotonergic receptors.

\section{5-HT $1 \mathrm{~B} / 1 \mathrm{D}$ Receptor}

The Buhot et al. (2003a,b; Wolff et al., 2003) seminal work (see also Drago et al., 2010) showed that $5-\mathrm{HT}_{1 \mathrm{~B}}$ receptor knockout mice exhibit a task-dependent selective learning facilitation; depending on the cognitive demand and/or age-related decline of spatial learning abilities (Table 4). In addition, pharmacological evidence indicates a possible involvement of hippocampal

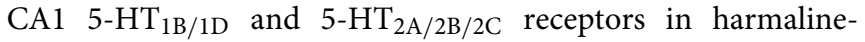
induced amnesia (Nasehi et al., 2014a). And 5- $\mathrm{HT}_{1 \mathrm{~B}}$ receptor activation disrupts delayed alternation (DAL) performance in mice (Woehrle et al., 2013) and chronic fluoxetine pretreatment blocks $5-\mathrm{HT}_{1 \mathrm{~B}}$ receptor- induced deficits; suggesting a 5$\mathrm{HT}_{1 \mathrm{~B}}$ receptor modulation in orbitofrontal-dependent DAL. The $5-\mathrm{HT}_{1 \mathrm{~B}}$-induced DAL deficits may provide a model for obsessive compulsive disorder (OCD; Woehrle et al., 2013). The above evidence is consistent with the possibility that 5$\mathrm{HT}_{1 \mathrm{~B}}$ receptor inverse agonists might be useful for reversing memory deficits (e.g., Meneses, 2001; Meneses and Tellez, 2015).

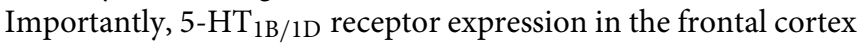
is correlated to memory impairment (Garcia-Alloza et al., 2004). Certainly, Drago et al. (2010) highlight that $5-\mathrm{HT}_{1 \mathrm{~B}}$ receptor is a candidate modulator of the mnemonic and motivationally related symptoms in psychiatric illnesses. Moreover, positive correlations exist between creative ability and $5-\mathrm{HT}_{1 \mathrm{~B}}$ receptor expression in gray matter of control subjects; as well as in Parkinson disease (PD) patients between depression and creative ability (Varrone et al., 2015); importantly, PD patients have poor semantic memory and creative ability (Varrone et al., 2015).

\section{Neurobiological Mechanisms in the Observational Learning of Aggression}

Suzuki and Lucas (2015) report that chronic passive exposure to aggression modifies expression of D2 receptor in the nucleus accumbens core (AcbC) and shell (AcbSh), and 5$\mathrm{HT}_{1 \mathrm{~B}}$ receptor in the medial $(\mathrm{MeA})$, basomedial (BMA), and basolateral (BLA) amygdala. And increased aggressive behavior reduced D2 receptor in bilateral AcbSh. Likewise, regardless of exposure aggression length $5-\mathrm{HT}_{1 \mathrm{~B}}$ receptor was augmented in bilateral BLA. Finally, low D2 receptor expression in the AcbSh significantly interacted with high $5-\mathrm{HT}_{1 \mathrm{~B}}$ receptor density in the BLA, predicting high levels of aggression in observer animals (Table 4). Suzuki and Lucas (2015) conclude that the dopamine-serotonin or AcbSh-BLA interactions; may be risk factors for aggression in observers chronically witness aggressive interactions (Suzuki and Lucas, 2015). Clearly, 5- $\mathrm{HT}_{1 \mathrm{~B}}$ receptor expression was useful in detecting learning and memory of aggression.

\section{5-HT $2 \mathrm{~A} / 2 \mathrm{~B} / 2 \mathrm{C}$ Receptors}

$\mathrm{Li}$ et al. (2015a) report that $5-\mathrm{HT}_{2 \mathrm{~A}}$ receptor is highly expressed in the medial septum-diagonal band of Broca complex (MS-DB), especially in parvalbumin (PV)-positive neurons linked to hippocampal theta rhythm (involved in normal and dysfunctional memory of PD). The medial forebrain bundle (MFB) lesions impaired working memory, hippocampal theta, decreased firing rate and density of MS-DB PVpositive neurons, rhythm, and DA levels in septohippocampal system and medial prefrontal cortex (mPFC). Intra-MS$\mathrm{DB}$ injection of the $5-\mathrm{HT}_{2 \mathrm{~A}}$ receptor agonist 4-Bromo-3,6dimethoxybenzocyclobuten-1-yl) methylamine hydrobromide (TCB-2) enhanced working memory, producing the opposite effects in control and lesioned and shortening TCB-effects; implicating dysfunctional 5- $\mathrm{HT}_{2 \mathrm{~A}}$ receptor. Li et al. (2015a) conclude that unilateral lesions of the MFB induced working memory deficit, and activation of $\mathrm{MS}-\mathrm{DB} 5-\mathrm{HT}_{2 \mathrm{~A}}$ receptor enhanced working memory, and involve monoamine levels in the hippocampus and mPFC. In addition, in a controlled cross-over PET study using a delayed match-to-sample task and the $5-\mathrm{HT}_{2 \mathrm{~A}}$ receptor antagonist $\left[{ }^{18} \mathrm{~F}\right]$ altanserin, Hautzel et al. (2011) report a cognition-induced modulation of serotonin in the orbitofrontal cortex (OFC). Importantly, Tomie et al. (2003) demonstrated an association between $5-\mathrm{HT}_{2 \mathrm{~A}}$ receptor expression and memory formation in Pavlovian autoshaping task. In addition, individual differences in impulsive action and $5-\mathrm{HT}_{2 \mathrm{~A}}$ receptor cortical variations have been noted (Fink et al., 2015). Also, D2 and $5-\mathrm{HT}_{2 \mathrm{~A}}$ receptors present genetic variants and modulate physiological prefrontal cortex efficiency during working memory and response to antipsychotics (Blasi et al., 2015). Moreover, although an association between $5-\mathrm{HT}_{2 \mathrm{~A}}$ receptor polymorphism (his452tyr) and memory performances in $\mathrm{AD}$ has been proposed; no differences in verbal memory were identified by Guglielmi et al. (2015).

Importantly, Barlow et al. (2015) report markers of serotonergic function in the orbitofrontal cortex and dorsal raphé nucleus predicting individual variation in spatialdiscrimination serial reversal learning. These authors conclude 
TABLE 4 | 5HT 2A/2B/2C receptor.

\begin{tabular}{|c|c|c|c|}
\hline Function/dysfunction & \multicolumn{2}{|l|}{ Findings } & References \\
\hline Parkinson disease & \multicolumn{2}{|c|}{$\begin{array}{l}\text { MS-DB 5-HT } 2 \text { A receptor activation enhanced WM, which may be due to changes in the } \\
\text { activity of septohippocampal network and monoamine levels in the hippocampus and mPFC }\end{array}$} & Li et al., 2015a \\
\hline Memory (match-to-sample task) & \multicolumn{2}{|c|}{ Cognition-induced modulation of serotonin in the OFC: PET study of $5-\mathrm{HT}_{2 \mathrm{~A}}$} & Hautzel et al., 2011 \\
\hline Memory (Pavlovian autoshaping) & \multicolumn{2}{|c|}{ 5- $\mathrm{HT}_{2 \mathrm{~A}}$ expression and $\mathrm{CR}$ (Pavlovian autoshaping) association } & Tomie et al., 2003 \\
\hline Spatial-discrimination serial reversal learning & \multicolumn{2}{|c|}{ Individual variations of $5-\mathrm{HT}_{2 \mathrm{~A}}$ in the OFC and dorsal raphé nucleus } & Barlow et al., 2015 \\
\hline Dopamine2 and 5- $\mathrm{HT}_{2 \mathrm{~A}}$ receptor variants & \multicolumn{2}{|c|}{$\begin{array}{l}\text { DRD2 and HTR2A genetic variants together modulate physiological prefrontal efficiency during } \\
\text { working memory and also modulate the response to antipsychotics }\end{array}$} & Blasi et al., 2015 \\
\hline Fmr1 KO mice (model of fragile $X$ syndrome); & $\begin{array}{l}\text { Combinations of } 5-\mathrm{HT}_{2 \mathrm{~B}} \text { or D1-Rs } \\
\text { or } 5 \mathrm{HT}_{2 \mathrm{~A}} \text { or } \mathrm{D} 2-\mathrm{Rs} \text { (low doses) }\end{array}$ & $\begin{array}{l}\text { Enhance Ras-PI3K/PKB signaling input, } \\
\text { GluA1-dependent synaptic plasticity and learning in Fmr1 } \\
\text { KO mice; without causing anxiety related side effects }\end{array}$ & Lim et al., 2014 \\
\hline 5- $\mathrm{HT}_{2 \mathrm{~B}}$ receptor expression & \multicolumn{2}{|c|}{$\begin{array}{l}\mathrm{Htr}_{2 B}-/- \text { mice, as shown by deficits in sensorimotor gating, in selective attention, in social } \\
\text { interactions and in learning and memory processes }\end{array}$} & $\begin{array}{l}\text { Pitychoutis et al., } \\
2015\end{array}$ \\
\hline Against epilepsy induced memory decline & \multicolumn{2}{|c|}{$\begin{array}{l}\text { Combined action at } \mathrm{MT} 1 / 2 \text { and } 5 \mathrm{HT}_{2 \mathrm{C}} \text { receptors, reduced the depolarization-evoked release } \\
\text { of glutamate, strong neuroprotective action and possible antioxidant properties of agomelatine }\end{array}$} & Vimala et al., 2014 \\
\hline Chronic microwave-induced cognitive deficit & \multicolumn{2}{|c|}{ Variations of $5-\mathrm{HT}_{1 \mathrm{~A}}$ and $5-\mathrm{HT}_{2} \mathrm{C}$ receptors expressions } & Li et al., 2015b \\
\hline
\end{tabular}

WM, working memory; OFC, orbitofrontal cortex; MPFC, medial prefrontal cortex; CR, conditioned responses; MT, melatonin.

that rats in the upper quintile of the distribution of perseverative responses during repeated $S-R$ reversals have significantly reduced levels of the 5-HT metabolite, 5-hydroxy-indoleacetic acid, in the OFC. Additionally, 5- $\mathrm{HT}_{2 \mathrm{~A}}$ receptor expression in the OFC of mid- and high-quintile rats was significantly reduced compared with rats in the low-quintile group. These perturbations were accompanied by an increase in the expression of monoamine oxidase-A (MAO-A) and MAO-B in the lateral OFC and by a decrease in the expression of MAO-A, MAO-B, and tryptophan hydroxylase in the dorsal raphé nucleus of highly perseverative rats. Barlow et al. (2015) found no evidence of significant differences in markers of DA and 5-HT function in the DMS or MAO expression in the ventral tegmental area of low- vs. high-perseverative rats; indicating that diminished serotonergic tone (probably, at least via $5-\mathrm{HT}_{2 \mathrm{~A}}$ receptor) in the OFC may be an endophenotype that predisposes to behavioral inflexibility and other forms of compulsive behavior (Barlow et al., 2015).

Moreover, Lim et al. (2014) investigated mechanisms of action of psychoactive drugs that modestly benefit the cognitive performance in fragile $\mathrm{X}$ patients (the most common form of inherited mental retardation); reporting that compounds activating $5 \mathrm{HT}_{2 \mathrm{~B}}$ receptor $\left(5 \mathrm{HT}_{2 \mathrm{~B}}\right)$ or dopamine (DA) subtype 1-like receptors (D1-Rs) and/or those inhibiting $5 \mathrm{HT}_{2 \mathrm{~A}}$ or D2 receptors moderately enhance Ras-PI3K/PKB signaling input, GluA1-dependent synaptic plasticity, and learning in Fmr1 knockout mice (Lim et al., 2014). Unexpectedly, combinations of these 5-HT and DA compounds at low doses synergistically stimulate Ras-PI3K/PKB signal transduction and GluA1-dependent synaptic plasticity and remarkably restore normal learning in Fmrl knockout mice without causing anxiety-related side effects. Lim et al. (2014) suggest that properly dosed and combined psychoactive drugs may effectively treat the cognitive impairment associated with fragile $\mathrm{X}$ syndrome. In addition, $\mathrm{Htr} 2 \mathrm{~B}^{-/-}$mice show deficits in sensorimotor gating, selective attention, social interactions as well as in learning and memory (i.e., fear conditioning and novel object recognition: STM and LTM) (Pitychoutis et al., 2015).

Regarding 5- $\mathrm{HT}_{2 \mathrm{C}}$ receptor, Vimala et al. (2014) highlight that epilepsy affects negatively cognitive function, producing depression, anxiety, etc. Mentioning among other issues that agomelatine is a novel antidepressant acting as melatonin MT1 and MT2 receptor agonist and $5-\mathrm{HT}_{2} \mathrm{C}$ receptor antagonist; producing reduction in the depolarization-evoked release of glutamate, strong neuroprotective action and possible antioxidant effects (Vimala et al., 2014); producing hippocampal neuronal cell survival and neurogenesis, neuroprotective effect in hippocampus and frontal cortex and the antioxidant potential may contribute to the protective action of agomelatine against epilepsy induced memory decline (Vimala et al., 2014). In addition, Walker and Foley (2010) report that administration of the $5-\mathrm{HT}_{2 \mathrm{C}}$ inverse agonist mianserin impaired autoshaped operant response on day 2 than any other agent tested. In addition, decreasing the length of the acquisition session to 1-h augmented the difficulty of the autoshaping task further modulating the consolidation effects produced by the $5-\mathrm{HT}_{2} \mathrm{C}$ ligands (Walker and Foley, 2010). Moreover, Li et al. (2015b) report that repeat exposition to $2.856 \mathrm{GHz}$ microwaves (averaging $5-30 \mathrm{~mW} / \mathrm{cm}^{2}$ ) affects spatial learning and 
TABLE 5 | $5 \mathrm{HT}_{3}$ receptor antagonist, neuroprotection.

\begin{tabular}{|c|c|c|}
\hline Function/dysfunction & Findings & References \\
\hline$A D$ & $\begin{array}{l}\text { Tropisetron, a potent } \alpha 7 \mathrm{nAChR} \text { agonist and } 5-\mathrm{HT}_{3} \text { receptor antagonist, also bound to the ectodomain of } \\
\text { amyloid precursor protein. Furthermore, tropisetron promoted greater improvements in memory current } \mathrm{AD} \\
\text { therapeutic drugs } \mathrm{AD} \text {. } \\
\text { In addition, tropisetron represents an attractive potential therapeutic drug to delay or prevent } \mathrm{MCl} \text { and } \mathrm{AD} \text {. } \\
\text { This drug is also used for the treatment of chemotherapy-induced emesis }\end{array}$ & $\begin{array}{l}\text { Hashimoto, } 2015 \\
\text { Fakhfouri et al., } 2014\end{array}$ \\
\hline \multirow[t]{2}{*}{$A \beta$ rat model of $A D$ in $M W M$} & $\begin{array}{l}\text { - Tropisetron might have a neuroprotective effect; tropisetron attenuated A } \beta \text {-induced hippocampal } \\
\text { neuroinflammation }\end{array}$ & Hashimoto, 2015 \\
\hline & Subtypes of $5-\mathrm{HT}_{3}$ receptor & Thompson, 2013 \\
\hline KO 5-HT 3 A receptor & $\begin{array}{l}\text { Loss of exercise-induced hippocampal neurogenesis and antidepressant effects, but not of learning } \\
\text { enhancement }\end{array}$ & Kondo et al., 2014 \\
\hline
\end{tabular}

$A D$, Alzheimer's disease; $M C l$, middle cognitive impairment; MWM, Morris water maze.

memory function, morphology structure of the hippocampus, electroencephalogram (EEG) and neurotransmitter content (amino acid and monoamine); including expression of 5$\mathrm{HT}_{1 \mathrm{~A}} 2 \mathrm{~A}$, and 2C receptors. Li et al. (2015b) demonstrated that chronic exposure to microwave could induce dose-dependent deficit of spatial learning and memory and inhibition of brain electrical activity, the degeneration of hippocampus neurons, and the disturbance of neurotransmitters; including hippocampal and cortical expression of $5-\mathrm{HT}_{1 \mathrm{~A}}$ and $5-\mathrm{HT}_{2} \mathrm{C}$ receptors.

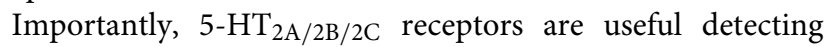
learning and memory changes and drug effects. Aloyo et al. (2009) remind us of inverse agonism at $5-\mathrm{HT}_{2 \mathrm{~A}}$ and $5-\mathrm{HT}_{2 \mathrm{C}}$ receptors.

\section{5- $\mathrm{HT}_{3}$ Receptor}

5- $\mathrm{HT}_{3}$ receptor antagonists (e.g., tropisetron, ondansetron) have a long dated antiamnesic effects, including attenuation of ageassociated memory impairment (e.g., Costall and Naylor, 1992; see also Shimizu et al., 2013). Recent evidence, from preclinical studies suggests that the interaction between amyloid- $\beta$ peptides $(\mathrm{A} \beta)$ and the $\alpha 7$ nicotinic acetylcholine receptor $(\alpha 7 \mathrm{nAChR})$ (Hashimoto, 2015) (Table 5). And tropisetron is also a $\alpha 7$ $\mathrm{nAChR}$ agonist and $5-\mathrm{HT}_{3}$ receptor antagonist; binding to amyloid precursor protein and enhancing memory in $\mathrm{AD}$ patients (Table 5). Importantly, 5- $\mathrm{HT}_{3}$ receptor antagonists have been useful in treatments such as chemotherapy-induced emesis to neuroprotection (Fakhfouri et al., 2014; Hashimoto, 2015). Certainly, subtypes of 5- $\mathrm{HT}_{3}$ receptor exist (Thompson, 2013); and their mechanisms are complex. For instance, Kozuska et al. (2014) deal with the multiple salt bridges in the intracellular domain of the $5 \mathrm{HT}_{3 \mathrm{~A}}$ receptor and these interactions increase the overall rigidity of the receptor, stabilize its low conducting state and affect the ligand cooperativity; suggesting that the allosteric effects of these regions on the receptor may be involved in a possible "reverse" allosteric modulation of $5 \mathrm{HT}_{3}$ receptor. In addition, it should be noted that agonist- and antagonistinduced up-regulation of surface $5-\mathrm{HT}_{3 \mathrm{~A}}$ receptor (Morton et al., 2015).
Moreover, Kondo et al. (2014) studied $5-\mathrm{HT}_{3 \mathrm{~A}}$ receptor subunit-deficient (htr3a-/-) mice revealing loss of exerciseinduced hippocampal neurogenesis and antidepressant effects, but not of learning enhancement (Table 5). Kondo et al. (2014) conclude that the $5-\mathrm{HT}_{3}$ receptor is the critical target of $5-\mathrm{HT}$ action in the brain following exercise, being indispensable for hippocampal neurogenesis and antidepressant effects induced by exercise.

\section{5- $\mathrm{HT}_{4}$ receptor}

It should be noted that earlier evidence indicated that $5-\mathrm{HT}_{4}$ receptor decreased in AD (see Eglen et al., 1995). Activation of $5-\mathrm{HT}_{4}$ receptor has pro-cognitive effects on memory tasks (e.g., Bockaert et al., 2011; Peñas-Cazorla and Vilaró, 2014; Ramirez et al., 2014; Claeysen et al., 2015). Notably, Madsen et al. (2011) observe cerebral $5-\mathrm{HT}_{4}$ receptor up-regulation starts at a preclinical stage of dementia and it continues while dementia is still at a mild stage and these authors speculate that this upregulation may be a compensatory effect of decreased levels of interstitial 5-HT, increase acetylcholine release or to counteract $A \beta$ accumulation and improved cognitive function. Hippocampal 5-HT4 receptor expression correlates inversely with human memory (Haarh et al., 2013; Table 6). Also, old rats have decreased 5-HT4 receptor expression and poor memory relative to adult (Table 6).

In addition, evidence suggests that serotonergic activity, via 5-HT4 receptors in hippocampal, striatum, and cortical areas, mediates memory function and provides further evidence for a complex and regionally specific regulation over 5-HT receptor expression during memory formation (Manuel-Apolinar et al., 2005).

Segu et al. (2010) report adaptive changes in cholinergic systems, which may circumvent the absence of $5-\mathrm{HT}_{4}$ receptor to maintain long-term memory under baseline conditions. In contrast, despite of adaptive mechanisms, the absence of 5- $\mathrm{HT}_{4}$ receptor aggravates scopolamine-induced memory impairments. The mechanisms whereby $5-\mathrm{HT}_{4}$ receptor mediates a tonic influence on ChAT activity and muscarinic receptors remain to be determined (Segu et al., 2010). Restivo et al. (2008) 


\section{TABLE 6 | $5 \mathrm{HT}_{4}$ receptor.}

\begin{tabular}{|c|c|c|}
\hline Function/dysfunction & Findings & References \\
\hline Memory & Activation has promnesic effects in rodents and humans & $\begin{array}{l}\text { Haahr et al., 2013; Peñas-Cazorla and } \\
\text { Vilaró, } 2014\end{array}$ \\
\hline Mechanisms in cognition & $\begin{array}{l}\text { Increased dendritic spines in the CA1 region of the hippocampus. } \\
\text { Neuronal activity and increased release of acetylcholine in the prefrontal cortex } \\
\text { and hippocampus. It is not synthesized in cholinergic cells } \\
\text { Pre-training SL65.0155 enhances olfactory memory discrimination, inducing hippocampal growth } \\
\text { dendritic spines; suggesting that selective } 5-\mathrm{HT}_{4} \text { stimulation increases structural plasticity in } \\
\text { learning activated hippocampal circuits }\end{array}$ & $\begin{array}{l}\text { Restivo et al., 2008; Marchetti et al., } \\
\text { 2011; Peñas-Cazorla and Vilaró, } 2014\end{array}$ \\
\hline Changes with age & Old rats decreased $5-\mathrm{HT}_{4}$ expression and poor memory relative to adult & $\begin{array}{l}\text { Waeber et al., 1996; Manuel-Apolinar } \\
\text { et al., 2005; Marchetti et al., } 2011\end{array}$ \\
\hline Memory & Hippocampal 5- $\mathrm{HT}_{4}$ expression correlates inversely with memory in humans. & Haahr et al., 2013 \\
\hline AD & This receptor and $\beta$-amyloid protein are present in early stages of AD & Madsen et al., 2011 \\
\hline
\end{tabular}

$A D$, Alzheimer's disease.

highlight that pharmacological modulation of synaptic efficacy is a prominent target in the identification of promnesic compounds and that pre-training administration of the $5-\mathrm{HT}_{4}$ receptor partial agonist SL65.0155 enhances olfactory discrimination and potentiates learning-induced dendritic spine growth in the mouse hippocampus; without affecting spine density in the pseudo-trained mice and, by itself, it does not promote spine growth. Likewise, the $5-\mathrm{HT}_{4}$ receptor antagonist $\mathrm{RS} 39604$ prior to SL65.0155 prevents both improved memory and additional formation of spines; thus confirming the $5-\mathrm{HT}_{4}$ receptor specificity of the observed effects (Restivo et al., 2008); and these authors conclude that $5-\mathrm{HT}_{4}$ receptor stimulation selectively increases experience-dependent structural plasticity in learningactivated hippocampal circuits.

Marchetti et al. (2011) have also highlighted that in developing rats as well as in rats ranging from 3 to 9 months of age, significant modifications of $5-\mathrm{HT}_{4}$ receptor expression have been observed (for references see Marchetti et al., 2011). These same authors propone that the poor memory formation observed in aged rats (Marchetti et al., 2011). And corresponding decreases in $5-\mathrm{HT}_{4}$ receptor expression in brain areas (e.g., hippocampus, amygdala, etc.) involved in memory formation, could explain improved memory, dendritic spines (Restivo et al., 2008), neuronal excitability and release of the neurotransmitter acetylcholine (Ach) (see Segu et al., 2010; Marchetti et al., 2011; Peñas-Cazorla and Vilaró, 2014). Clearly, 5- $\mathrm{HT}_{4}$ receptor is useful neural marker of dysfunctional and memory formation as well as therapeutic target. Moreover, studying 5-HT expression during memory formation is giving new fresh insights (e.g., Haahr et al., 2013). Importantly, Haahr et al. (2013) report that hippocampal 5- $\mathrm{HT}_{4}$ receptor expression correlates inversely with human memory performance.

\section{$5-\mathrm{HT}_{5}$}

As mentioned above, Cavallaro (2008) reported that passive avoidance memory involves expression of several 5-HT receptors, including $5-\mathrm{HT}_{5 \mathrm{~A}} \cdot 5-\mathrm{HT}_{5}$ receptor occurs in brain areas implicated in learning and memory. Post-training administration of the $5-\mathrm{HT}_{5 \mathrm{~A}}$ receptor antagonist SB-6995516 decreased CR during short-term (STM; 1.5-h; at $0.1 \mathrm{mg} / \mathrm{kg}$ ) and long-term memory (LTM; 24-h; at $3.0 \mathrm{mg} / \mathrm{kg}$ ). Moreover, considering that there are no selective $5-\mathrm{HT}_{5 \mathrm{~A}}$ receptor agonists, next, diverse doses of the serotonin precursor l-tryptophan were studied during STM and LTM, showing that l-tryptophan (5-100 mg/kg) facilitated performance, particularly at $50 \mathrm{mg} / \mathrm{kg}$. In interactions experiments, l-tryptophan $(50 \mathrm{mg} / \mathrm{kg})$ attenuated the impairment effect induced by SB-699551 (either 0.3 or $3.0 \mathrm{mg} / \mathrm{kg}$ ) (Gonzalez et al., 2013). All together this evidence suggests that the blockade of $5-\mathrm{HT}_{5 \mathrm{~A}}$ receptor appear to be able to impair STM and LTM $(24 \mathrm{~h})$ in autoshaping task, while its stimulation might facilitate it. Of course further investigation is necessary, meanly with selective $5-\mathrm{HT}_{5 \mathrm{~A}}$ compounds (Gonzalez et al., 2013). Interestingly, Yamazaki et al. (2014, 2015) reported that a $5-\mathrm{HT}_{5 \mathrm{~A}}$ receptor antagonist ameliorates positive symptoms and cognitive impairment in animal models of schizophrenia and in aged rats and induced-amnesia. An analogous case is observed regarding $5-\mathrm{HT}_{1 \mathrm{~A}}$ partial agonists (see above).

Returning to 5- $\mathrm{HT}_{5}$ receptor, Karimi et al. (2013) report that it has long been known that hippocampal spatial memory and the ability to navigate through space are sexually dimorphic traits among mammals, and numerous studies have shown that these traits can be altered by means of sex hormone manipulation. Male and female rat pups were injected with estradiol and testosterone respectively, at early stage of their lives to examine the effect of sex hormone manipulation on mRNA expression of Slc9a4, Nr3c2, Htr5b, and Mas1; among other results, these authors report that expressions of these genes are strongly influenced by sex hormones in both the frontal cortex and hippocampus, especially in male hippocampus, in which expression of all genes were up-regulated. Htr5b was the gene that was affected only in the males (Karimi et al., 2013). Hence, considering the pharmacological evidence mentioned above, probably learning and memory might be affected in these animals. 


\section{5-HT 6 receptor}

Diverse $5-\mathrm{HT}_{6}$ receptor antagonists produce promnesic and/or antiamnesic effects in conditions, such as memory formation, age-related cognitive impairments; memory deficits in models of diseases such as schizophrenia, $\mathrm{PD}$ and $\mathrm{AD}$ (e.g., King et al., 2008; Claeysen et al., 2015). However, not all papers report promnesic and/antiamnesic effects of $5-\mathrm{HT}_{6}$ receptor antagonists (e.g., Thur et al., 2014) (Table 7); probably related to timing, drug and memory task used. Memory, aging, and $\mathrm{AD}$ modify $5-\mathrm{HT}_{6}$ receptors and signaling cascades; and $5-\mathrm{HT}_{6}$ drugs modulate memory, which is accompanied with neural changes. Indeed, in an elegant work Eskenazi et al. (2015) manipulated selectively overexpression of $5-\mathrm{HT}_{6}$ receptor in either direct or indirect pathway striatal mediumspiny neurons (dMSN and iMSN, respectively), revealing that increased $5-\mathrm{HT}_{6}$ receptor expression in iMSNs delays instrumental learning and in DLS facilitates behavioral flexibility after habitual responding. It should be noted that $5-\mathrm{HT}_{6}$ receptor expression decreases during memory (e.g., HuertaRivas et al., 2010; Ramirez et al., 2014). In addition, de Bruin and Kruse (2015) suggest that cognition could be improved by $5-\mathrm{HT}_{6}$ receptor antagonists, by increasing the number of NCAM PSA-immunoreactive neurons in the dendate gyrus, inhibit mTOR and Fyn-tyrosine kinase and interact with DARPP-32.

Notably, 5- $\mathrm{HT}_{6}$ receptor antagonists are, among, serotonergic therapies for cognitive symptoms in $\mathrm{AD}$ (e.g., Ramirez et al., 2014). Indeed, Wilkinson et al. (2014) report safety and efficacy of idalopirdine, a $5-\mathrm{HT}_{6}$ receptor antagonist, in patients with moderate $\mathrm{AD}$. In addition, $5-\mathrm{HT}_{6}$ receptor is providing new insights about plasticity (Dayer et al., 2015). For example, at early stages of neuronal development, expression of $5-\mathrm{HT}_{6}$ receptor constitutively regulates the activity of the cyclin-dependent kinase (Cdk) 5 and, through this mechanism, controls cellular processes involved in circuit formation (e.g., neuronal migration, neurite outgrowth). In addition, $5-\mathrm{HT}_{6}$ receptor modulates developmental targets, including Fyn, Jab1, and mammalian target of rapamycin (mTOR). In therapeutic terms such as blockade of pathological over-activation of the mTOR pathway induced by early life insults in rodents and normalizes the associated social and episodic memory deficits. It should be noted that $5-\mathrm{HT}_{6}$ receptor and $\mathrm{Cdk} 5$; and the latter mediates neuronal differentiation (e.g., hippocampus, striatum) in an agonist-independent manner (Seo and Tsai, 2014). In addition, $\mathrm{Ha}$ et al. (2015) report that $5-\mathrm{HT}_{6}$ receptor directly interacts with SNX14 (protein-coupled receptors/regulators of G protein signaling), which regulates internalization; degradation of $5-\mathrm{HT}_{6}$ receptor and cAMP production. This finding might be related to the evidence that $5-\mathrm{HT}_{6}$ receptor agonists and antagonists modulate cAMP production and improve memory formation (e.g., Meneses et al., 2011c). We do not know yet why 5$\mathrm{HT}_{6}$ receptor agonists and antagonists (e.g., Woods et al., 2012) may facilitate memory or may reverse amnesia in some memory tasks. However, $5-\mathrm{HT}_{6}$ receptor inverse agonist might be useful (e.g., Hostetler et al., 2014; but see also Benhamú et al., 2014).

\section{TABLE 7 | 5-HT 6 receptor.}

\begin{tabular}{|c|c|c|}
\hline Function/dysfunction & Findings & References \\
\hline Memory/models of diseases & $\begin{array}{l}\text { Antagonism produce promnesic and/or antiamnesic effects, including memory formation, } \\
\text { age-related cognitive impairments; memory deficits in models for diseases such as } \\
\text { schizophrenia, Parkinson, and AD }\end{array}$ & $\begin{array}{l}\text { Meneses et al., } 2011 \text { a; Ramirez et al., } \\
\text { 2014; but always see Thur et al., } \\
2014\end{array}$ \\
\hline Memory, aging, and AD & Modify $5-\mathrm{HT}_{6}$ receptor and signaling cascades & Ramirez et al., 2014 \\
\hline Expression & $5-\mathrm{HT}_{6}$ decreases during memory & $\begin{array}{l}\text { Huerta-Rivas et al., 2010; Ramirez } \\
\text { et al., } 2014\end{array}$ \\
\hline Expression & $\begin{array}{l}\text { Overall, increased } 5-\mathrm{HT}_{6} \text { receptor expression in iMSNs slowed instrumental learning and in } \\
\text { DLS facilitated behavioral flexibility after habitual responding }\end{array}$ & Eskenazi et al., 2015 \\
\hline Cognitive therapy & Idalopirdine antagonist administration improves memory in patients with moderate AD & $\begin{array}{l}\text { Wilkinson et al., 2014; see also } \\
\text { Ramirez et al., } 2014\end{array}$ \\
\hline Mechanisms & $\begin{array}{l}\text { Blocking this receptor decreases over-activation of mTOR when there are insults in early life } \\
\text { rodent deficits associated this normalize the social and episodic memory }\end{array}$ & Dayer et al., 2015 \\
\hline \multirow[t]{2}{*}{ Signaling molecules } & $\begin{array}{l}\text { Cdk5 activity regulated and controlled by this neuronal migration and neurite outgrowth. } \\
\text { Cdk5 modulates the activity of Fyn, Jab1 and mTOR }\end{array}$ & Dayer et al., 2015 \\
\hline & $\begin{array}{l}\text { SNX } 14 \text { is an endogenous negative regulator of } 5-\mathrm{HT}_{6} \text { receptor, modulating its signaling and } \\
\text { trafficking Also, SNX } 14 \text { internalizes and degrades } 5-\mathrm{HT} 6 \text { receptor }\end{array}$ & Ha et al., 2015 \\
\hline
\end{tabular}

AD, Alzheimer's disease; Cdk5, cyclin-dependent kinase; mTOR, mammalian target of rapamycin; dMSN, direct or indirect, iMSM pathway medium-spiny neurons. 


\section{5-HT 7 Receptor}

Recently Nikiforuk (2015) is providing perspectives of $5-\mathrm{HT}_{7}$ receptor in the search for treatments for CNS disorders: including normal and dysfunctional serotonin-induced phase shifting of the circadian rhythm control of memory as well as locomotor and exploratory activity, anxiety, depression; and Guseva et al. (2014) about molecular mechanisms responsible for the $5-\mathrm{HT}_{7}$ receptormediated signaling. Gasbarri and Pompili (2014) noted that 5$\mathrm{HT}_{7}$ receptor antagonism might have antiamnesic effects (see also Horisawa et al., 2013). Gasbarri et al. (2008) suggested that 5$\mathrm{HT}_{7}$ receptor blockade had procognitive effect, when the learning task implicated a high degree of difficulty. Others report that 5$\mathrm{HT}_{7}$ receptor agonists facilitate memory and have antiamnesic effects (Table 8); remaining clarifying why of the paradoxical effects.

Notably, Saroja et al. (2014), highlight that although evidence about monoamine receptor (MAR) biochemistry and pharmacology in aging exists, work on MAR complexes rather than subunits is limited; in consequence, MAR complexes in hippocampi of three different age groups (3-12 and 18 months) in mice and to link MAR changes to spatial memory retrieval in the water maze were determine (Table 8). MAR complexes were separated in order to show the pattern of dopamine and $5-\mathrm{HT}_{1 \mathrm{~A}}$ and $5-\mathrm{HT}_{7}$ receptors and colocalizations (Saroja et al., 2014). For instance, D1-D2 and $5-\mathrm{HT}_{7}$ receptors containing receptor complex levels decreased with age while $5-\mathrm{HT}_{1 \mathrm{~A}}$ receptorcontaining complex was increasing. D1, 5- $\mathrm{HT}_{7}$, and $5-\mathrm{HT}_{1 \mathrm{~A}}$ receptor complex correlated with good retrieval memory in the water maze; hence, individual monoamine receptors are linked to spatial memory and are modulated by age. However, Beaudet et al. (2015) mention that changes in the level of transcription of the $5-\mathrm{HT}_{7}$ receptor mRNA did not account for the age-related difference observed at the protein level, at least in hippocampal CA3 region; besides, $5-\mathrm{HT}_{7}$ receptor might also be putatively subjected, across aging, to modifications in their affinity or to changes in their coupling to G-proteins or other signaling

TABLE 8 | 5-HT 7 receptor.

\begin{tabular}{|c|c|c|}
\hline Function/dysfunction & Findings & References \\
\hline Brain development, autism, depression & $\begin{array}{l}\text { Contributes to networks during development and in the mature brain } \\
\text { remodel, thus participating in emotion and cognition }\end{array}$ & $\begin{array}{l}\text { Ciranna and Catania, 2014; Guseva et al., } \\
\text { 2014; Volpicelli et al., 2014; Nikiforuk, } 2015\end{array}$ \\
\hline Memory/amnesia & $\begin{array}{l}\text { Apparently } 5-\mathrm{HT}_{7} \text { receptor agonists and antagonist might facilitate memory } \\
\text { formation and/or have anti-amnesic effects }\end{array}$ & e.g., Nikiforuk, 2015 \\
\hline Amnesia & Antagonism might have antiamnesic effects & $\begin{array}{l}\text { Tajiri et al., 2012; Waters et al., 2012; } \\
\text { Horisawa et al., 2013; Nikiforuk et al., 2013; } \\
\text { Gasbarri and Pompili, 2014; Westrich et al., } \\
2015\end{array}$ \\
\hline Memory/amnesia & Agonism has procognitive and/or antiamnesic effects & $\begin{array}{l}\text { Perez-García and Meneses, 2005; } \\
\text { Pérez-García et al., 2006; Costa et al., 2012; } \\
\text { Eriksson et al., 2012; Di Pilato et al., 2014; } \\
\text { Freret et al., 2014; Ruocco et al., 2014; } \\
\text { Meneses et al., } 2015\end{array}$ \\
\hline
\end{tabular}

\begin{tabular}{|c|c|c|}
\hline Memory and mRNA expression & $\begin{array}{l}\text { Higher level of expression of } 5-\mathrm{HT}_{7} \text { receptor mRNAs in autoshaping-trained } \\
\text { relative to untrained groups }\end{array}$ & Pérez-García et al., 2006 \\
\hline Memory time-course & $\begin{array}{l}\text { Progressive memory and mRNA } 5-\mathrm{HT}_{1 \mathrm{~A}} \text { or } 5-\mathrm{HT}_{7} \text { receptors expression } \\
\text { monotonically augments or declines in prefrontal cortex, hippocampus and } \\
\text { raphe nuclei, respectively }\end{array}$ & Perez-Garcia and Meneses, 2009 \\
\hline Aging and memory & $\begin{array}{l}\text { Hypothesis: a decreased expression of } 5-\mathrm{HT}_{7} \text { receptor in } \mathrm{CA} 3 \text { hippocampal } \\
\text { could account for impairments of the shift between spatial strategies across } \\
\text { aging }\end{array}$ & Beaudet et al., 2015 \\
\hline Signaling & $\begin{array}{l}\text { Coupled to a } G_{S} \text { protein, stimulation activates the } A C \text { increased cAMP, in } \\
\text { addition, } 5-H T_{7} \text { is associated to } \mathrm{G} 12 \text {; a small GTPase protein of the Rho } \\
\text { family. } \mathrm{G}_{\alpha s} \text { and } \mathrm{G}_{\alpha 12} \text { are involved in the regulation of TrkB expression by } \\
5-\mathrm{HT}_{7} \text {, depending on the model of study }\end{array}$ & Guseva et al., 2014; Samarajeewa et al., 2014 \\
\hline Monoamine complex and memory & $\begin{array}{l}\mathrm{D} 1, \mathrm{D} 2 \text { and } 5 \mathrm{HT}_{7} \text { decreasing together with age, } 5-\mathrm{HT}_{1 \mathrm{~A}} \text { receptors } \\
\text { containing complex MAR increase with age. The receptors MAR, } 5-\mathrm{HT}_{7} \text {, } \\
5-\mathrm{H} \mathrm{T}_{7 \mathrm{~A}} \text { and } \mathrm{D} 1 \text {, correlate with changes in spatial memory, which are } \\
\text { modulated by age }\end{array}$ & Saroja et al., 2014 \\
\hline
\end{tabular}

MWM, Morris Water Maze; MAR, monoamine receptor complex (i.e., D1, D2, and 5-HT7 containing receptors). 
pathways. Notably, Beaudet et al. (2015) suggest that a decreased expression of $5-\mathrm{HT}_{7}$ receptor in CA3 hippocampal could account for impairments of the shift between spatial strategies across aging (Table 8).

Moreover, when the time-course $(0-120 \mathrm{~h})$ of autoshaped $\mathrm{CR}$ is progressive; then mRNA $5-\mathrm{HT}_{1 \mathrm{~A}}$ or $5-\mathrm{HT}_{7}$ receptors expression is monotonically augmented or decreased in prefrontal cortex, hippocampus and raphe nuclei, respectively (Perez-Garcia and Meneses, 2009). Hence, 5- $\mathrm{HT}_{1 \mathrm{~A}}$ and $5-\mathrm{HT}_{7}$ receptors expression might be regulated by the level of memory formation and to be brain areas dependent. Moreover, the cyclic adenosine monophosphate (cAMP) is a second messenger and a central component of intracellular signaling pathways that regulate a wide range of biological functions, including memory (e.g., Kandel, 2001). And progressive time-course of memory formation in an autoshaping learning task (Pérez-García and Meneses, 2008); shows that ex-vivo cAMP production from trained and over-trained groups compared to untrained ones, the former group had the highest levels of cAMP and the latter rats showed increased production but less relative to trained rats. Importantly these changes varied according with normal memory or amnesia and brain areas; hence cAMP production is important in the signaling case in mammalian memory formation (Pérez-García and Meneses, 2008).

The above findings should be considered in the context that apparently $5-\mathrm{HT}_{7}$ receptor agonists and antagonist (e.g., Nikiforuk, 2015) might facilitate memory formation and/or have anti-amnesic effects. Other interesting recent finding is that according with Rojas et al. (2014) serotonin regulates neurite outgrowth through $5-\mathrm{HT}_{1 \mathrm{~A}}$ and $5-\mathrm{HT}_{7}$ receptors in cultured hippocampal neurons. Certainly, De Filippis et al. (2015) highlight that promnesic effects of the $5-\mathrm{HT}_{7}$ receptor agonist LP-211 treatment strongly depend on the basal level of performance. Notably, Ruocco et al. (2014) report that $5-\mathrm{HT}_{7}$ receptor stimulation improves selective spatial attention and produces permanent changes in several neural markers, including expression of glutamatergic receptors and dopamine transporter (DAT).

Very importantly, 5-HT7 receptor can form heterodimers with 5-HT1A receptors both in-vitro and in-vivo (see Guseva et al., 2014) and according with these authors, from the functional point of view, heterodimerization decreases Giprotein coupling of 5-HT1A receptor and attenuates receptormediate deactivation of G-protein-gated potassium (GIRK) channels, without substantial changes in the coupling of 5HT7 receptor to the Gs-protein. Moreover, heterodimerization significantly facilitated internalization of 5-HT1A receptor, while internalization kinetics of 5-HT7 receptor was decelerated upon heterodimerization (see Guseva et al., 2014).

\section{Factors Responsible for Inconsistencies among Laboratories}

BOX 1 | Factors responsible for inconsistencies among laboratories.

Certainly, a number of factors might be produce similar results or be responsible for some inconsistencies among laboratories studying memory; which are complex and multi focal; which should provide an analytic framework offering key clues. Indeed, analysis of memory should include behavioral tasks, type of memory, the dynamic hierarchy of neural markers and brain areas involved in memory formation (e.g., Euston et al., 2012; Eskenazi et al., 2015) vs. no training, amnesia, anti-amnesic effects or forgetting (e.g., see below). Likewise, the species and the nature of behavioral task (e.g., appetitively or aversively motivated), curves of behavioral acquisition (i.e., multi-trial or two trials task) or patterns of behavioral responses (progressive vs. all or none response), cognitive demand (easy or difficult task), timing of drug administration (pre-training, post-training or pretest) and kind of drug (e.g., agonist or antagonist), protocols of training and testing together with neurobiological markers (e.g., Duewer et al., 1995; Patton, 1995) accompanying mnemonic processes deserve attention. Among the behavioral memory tasks available (e.g., Peele and Vincent, 1989; Myhrer, 2003; Lynch, 2004); importantly, the implementation of new instruments for measuring memory in behavioral tasks assists in gaining deeper insight into learning and memory processes (e.g., Cook et al., 2004; Walker et al., 2011; Markou et al., 2013; Leger et al., 2014; Wolf et al., 2014).

\section{Neural Transporters, Memory, Forgetting and Drugs}

Notwithstanding neurotransmission systems are related to memory formation, amnesia and/or therapeutic targets for memory alterations, the role of transporters $\gamma$-aminobutyric acid (GABA, GAT1), glutamate (neuronal glutamate transporter excitatory amino acid carrier; EACC1), dopamine (DAT) and serotonin (SERT) is poorly understood. Emerging evidence indicates that memory formation (short- and long-term memory; STM and LTM, respectively) in a Pavlovian/instrumental autoshaping (see Box 1) is associated to up-regulation of prefrontal cortex GAT1 and EAAC1, striatal SERT, DAT and EACC1; while, hippocampal EACC1, GAT1, and SERT are downregulated (Tellez et al., 2012a,b; Table 9; Figure 1). Moreover, pharmacological analysis shows that methamphetamine (METH)- induced amnesia down-regulated SERT, DAT, EACC1, and GAT1 in hippocampus and the GAT1 in striatum; no-changes are observed in prefrontal cortex. Fluoxetine (antidepressant, 5-HT uptake inhibitor) improved memory consolidation (particularly LTM), which is associated to DAT, GAT1 (prefrontal cortex) up-regulation, but GAT1 (striatum) and SERT (hippocampus) down-regulation. Fluoxetine plus METH prevented amnesia, which was associated to DAT, EACC1 and GAT1 (prefrontal cortex), SERT and DAT (hippocampus) and EACC1 or DAT (striatal) up-regulation.

\section{Memory Formation/Forgetting and SERT Expression}

Forgetting in Pavlovian/instrumental autoshaping is associated to up-regulation of GAT1 (PFC and HIP) and DAT (PFC) while SERT (HIP) is down-regulated; no-changes are observed in striatum (Table 9). Methamphetamine alone not affected forgetting but up-regulates hippocampal DAT and EACC, prefrontal cortex DAT and striatal GAT1 or EACC1. Fluoxetine alone prevents forgetting, which is associated to striatal GAT1 and hippocampal DAT up-regulation, but prefrontal cortex GAT1 down-regulation. Fluoxetine plus METH prevent forgetting, which is associated to hippocampal DAT, prefrontal cortex SERT and striatal GAT1, DAT, or SERT up-regulation, 


\section{BOX 2 | Autoshaping tasks.}

Autoshaping memory tasks have been focus by several research groups (e.g., Brown and Jenkins, 1968; Myer and Hull, 1974; Atnip, 1977; Oscos et al., 1988; Bussey et al., 1997, 2013; Lindner et al., 2003; Vanover et al., 2004; Ballaz et al., 2007; Rodriguez et al., 2008; Walker and Foley, 2010; Walker et al., 2011; Tomie et al., 2012; Krynetskiy et al., 2013; Markou et al., 2013; Gallistel et al., 2014; Holland et al., 2014; Lesaint et al., 2014; Talpos et al., 2014; Eskenazi et al., 2015 ; Talpos and Shoaib, 2015; in several animal species (e.g., Wasserman, 1981) including humans (Wilcove and Miller, 1974; Pithers, 1985). According with Holland et al. (2014), "autoshaping" or "sign-tracking" phenomenon has recently attracted considerable attention as a platform for studying individual differences in impulsivity, drug sensitization, and other traits associated with vulnerability to drug addiction. Autoshaping has been also used for detecting effects induced by memory, amnesia, drugs, genetic variations, aging and neural markers (e.g., Tomie et al., 2003, 2012; Vanover et al., 2004; Rodriguez et al., 2008; Fitzpatrick et al., 2013; Markou et al., 2013; Talpos et al., 2014). Notably, autoshaping is an associative automatized learning task (see below), and during memory consolidation of Pavlovian/instrumental autoshaping learning task, dentate gyrus, hippocampal CA1, basolateral amygdaloid nucleus and prefrontal cortex are require (see below). It should be noted that an important innovation, and growingly popular method of assessing cognitive functions is the automated touchscreen platform (e.g., Abela et al., 2013; Talpos et al., 2014; Delotterie et al., 2015), used for diverse cognitive tasks, comparable those in employ in human subjects (Horner et al., 2013), including autoshaping (e.g., Gallistel et al., 2014; Talpos et al., 2014; Silverman et al., 2015).

Autoshaping learning tasks involve classical and instrumental conditioning (i.e., stimulus-stimulus and stimulus-responding conditioning). It should be mentioned that long-lasting memories are most efficiently formed by multiple training sessions separated by appropriately timed intervals. Autoshaping meets this criterion and it allows modeling of behavioral situations requiring integration of information obtained from sign- and goal-tracking settings; representing memory of self-taught settings (Meneses, 2013, 2014). Certainly, autoshaping tasks (Pavlovian or instrumental; and Pavlovian/instrumental may produce initial modest and/or variable levels of conditioned responses (CR). Importantly, memory formation, amnesia and forgetting in Pavlovian/instrumental paradigms are accompanied by changes in neural markers, including 5-HT, glutamate, dopamine, and GABA transporters expression levels (Tomie et al., 2003; Tellez et al., 2012a,b), 5-HT receptor expression and CAMP production (Meneses, 2013). Certainly, forgetting as therapeutic targets for dysfunctional memory it has been little explored. As above mentioned, similar results, including pharmacological and neurobiological changes to those reported in autoshaping have been described in other memory behavioral tasks (for review see King et al., 2008; Marcos et al., 2008; Da Silva Costa-Aze et al., 2012; Reichel et al., 2012; Woods et al., 2012; Haahr et al., 2013; Freret et al., 2014; Nasehi et al., 2014b; Seyedabadi et al., 2014; Subramaniyan et al., 2014; Wilkinson et al., 2014; Delotterie et al., 2015; Sase et al., 2015; Westrich et al., 2015).

\section{Behavioral parameters during STM and LTM}

In addition to measuring CR in autoshaping, head-pokes (HP) during each training/testing session and head-pokes during CS (HP-CS) have recorded. These parameters provide information about exploration activity (HP) and food- intake motivation (Tellez et al., 2012a). For instance, as CR becomes progressive, HP-CS provides information on the association of CS-US and CR-US.

\section{Maximum level of $\mathbf{C R}$}

It should be noted that as animals present different levels of $\mathrm{CR}$, these values are normalized and the maximal CR level attained for each rat at $48 \mathrm{~h}$ is considered as $100 \%$ of performance. This value is then used to calculate the proportion or percentage of CR observed at $1.5,24$, and $216 \mathrm{~h}$ and the data of $1.5 \mathrm{~h}$ and $24 \mathrm{~h}$ are used as illustration; and multiple comparisons, including memory, forgetting, time vs. treatments for all behavioral parameters (Meneses and Tellez, 2015).

\section{Memory, amnesia and forgetting and neural transporters analysis}

As already mentioned autoshaping procedures produce variable levels of $\mathrm{CR}$ and a number of laboratories have been using autoshaping. It should be noted that, reproducibility among studies is important and expected that to vary (e.g., Marcus, 2014).

but prefrontal cortex GAT1 down-regulation. Together these results show that forgetting provokes primarily hippocampal and prefrontal cortex transporters changes; it represents a cognitive process hardly modifiable and its prevention could causes different transporters expression patterns. Notably, together the results suggest that: (1) memory formation, amnesia and antiamnesic effects are associated to specific patterns of transporters expression; (2) STM and LTM, forgetting and anti-forgetting effects are associated to specific patters of transporters expression and brain areas; (3) amnesia and forgetting affect different brain areas and produce differential patters of transporter expression. Hence, in pharmacological and neuroanatomical terms, amnesia and forgetting differ.

\section{Neural Transporters and Brain Functions and Dysfunctions}

It should be noted that neural transporters regulate intrasynaptic levels of neurotransmitter, which allows a global picture of synapses. Moreover, diverse evidence indicates that memory formation, forgetting, amnesia, and/or anti-amnesic effects can also be modulated by changes in the expression of neurotransmitter transporters (e.g., Schmitt and Hiemke, 2002; Chen et al., 2011; Reichel et al., 2012; Yang et al., 2013). Hence, a brief overview of evidence involving GAT1, EAAT1, SERT, and
DAT as well other neurobiological markers regarding memory and other cerebral functions is include.

\section{GAT 1}

Attention deficit/hyperactivity disorder (ADHD) is featured by hyperactivity, impaired sustained attention, impulsivity, and usually varying degrees of dysfunctional learning and memory (see also Meneses et al., 2011b) and motor incoordination (Yang et al., 2013). Importantly, Yang et al. (2013) report that GAT1 gene knockout $(\mathrm{KO})$ mouse $\left(\mathrm{GAT} 1^{-/-}\right.$) is hyperactive and exhibit impaired memory performance (Morris water maze). KO GAT1 mice have low levels of attentional focusing and increased impulsivity; the hyperactivity in these $\mathrm{KO}$ mice is reduced by both methylphenidate and amphetamine; Yang et al. (2013) suggest that GAT1 KO mouse is a new animal model for ADHD studying and GAT1 may be a new target to treat ADHD. Schmitt and Hiemke (2002) note that GABA is cleaved from the synaptic cleft by uptake (see Hu and Quick, 2008), via specific transporters and inhibition of such transporters increases the effectiveness of physiologically released GABA. Increased GABAergic neurotransmission has an impact on learning and memory. Indeed, tiagabine, a GABA-transporter inhibitor, impaired learning (Morris water-maze) and retrieval (only at the probe trial; Schmitt and Hiemke, 2002). But, 
TABLE 9 | Neural transporters during STM and LTM, amnesia (methamphetamine), forgetting, (fluoxetine) improved LTM, (fluoxetine) anti-forgetting effects and anti-amnesic (fluoxetine plus methamphetamine) effects.

\begin{tabular}{ll}
\hline Cognitive process & Neural transporters expression of transporters in brain areas \\
\hline STM and LTM & Up-regulation of PFC GAT1 and EAAC1, striatal SERT, DAT and EACC1; while, HIP EACC1, GAT1 and SERT are down-regulated \\
Amnesia & Down-regulated SERT, DAT, EACC1 and GAT1 in HIP the GAT1 in striatum; no-changes are observed in PFC \\
Forgetting & Up-regulation of GAT1 (PFC and HIP) and DAT (PFC) while SERT (HIP) is down-regulated; no-changes are observed in striatum \\
Improved LTM & DAT, GAT1 (PFC up-regulation), but GAT1 (striatum) and SERT (HIP) down-regulation \\
Anti-forgetting effects & Striatal GAT1 and HIP DAT up-regulation, but PFC GAT1 down-regulation \\
Anti-amnesic effects & DAT, EACC1 and GAT1 (PFC), SERT and DAT (HIP) and EACC1 or DAT (striatal) up-regulation
\end{tabular}

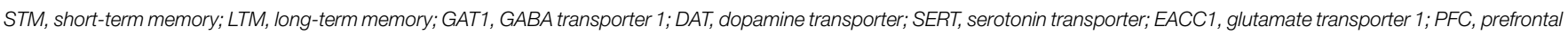
cortex; HIP, hippocampus.

A Memory Formation

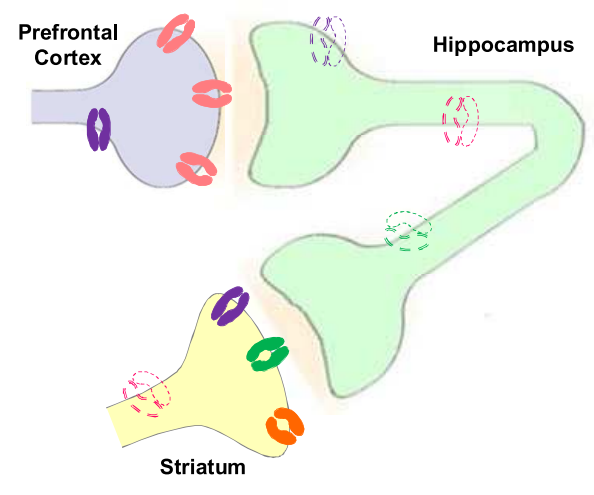

9 SERT 9 EACC1 9 DAT 9 GAT1

\section{B Temporal-course of Forgetting}

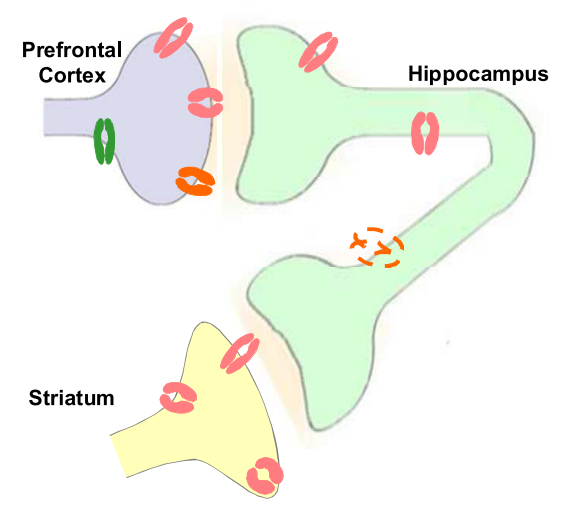

slight color refers to down-regulation. GAT1, GABA transporter 1; EAAC1, neuronal glutamate transporter excitatory amino acid carrier-1; DAT, dopamine transporter SERT, serotonin transporter (modified from

Tellez et al., 2010, 2012a,b).
FIGURE 1 | Schematic representation of changes with Western blot analysis of neural transporters in prefrontal cortex, hippocampus and striatum during memory formation and temporal-course of forgetting. Strong color refers to up-regulation,
Sałat et al. (2015) note that tiagabine slightly decreased memory but did not augment that induced by scopolamine. According with Shi et al. (2012), homozygous GAT1 ${ }^{(-/-)}$ mice exhibit impaired hippocampus-dependent learning and memory; and they evaluated the impact of endogenous reduced GABA reuptake on cognitive behaviors. Learning and memory of heterozygous $\mathrm{GAT} 1^{(+/-)}$mice was determined in passive avoidance and Morris water maze; showing that GAT1 $(+/-)$ mice displayed increased learning and memory, decreased anxiety-like behaviors, and highest synaptic plasticity relative to wild-type and homozygous GAT1 $1^{(-/-)}$mice; and authors conclude that a moderate reduction in GAT1 activity is associated to learning and memory facilitation (Shi et al., 2012); which is consistent, in part, with GAT1 reduced and increased expression in autoshaping amnesia, forgetting and improved memory as well as anti-amnesic and anti-forgetting effects (see Table 10). In addition, Pang et al. (2011) testing the GABAergic immunotoxin; GAT1-saporin (GAT1-SAP), report no alterations in spatial reference memory. But GAT1-SAP impaired the platform location in a delayed match to position test (changing daily the platform location). In the active avoidance task, intraseptal GAT1-SAP impaired extinction but not acquisition (Pang et al., 2011). In contrast, GAT1-Saporin into the medial septum/vertical limb of the diagonal band (MS/VDB) spared mnemonic function and use of environmental cues; however, self-movement cue processing was compromised (Köppen et al., 2013).

\section{EAAT1}

According with Chen et al. (2011), an imbalance of neurotransmitters (e.g., glutamate, acetylcholine, dopamine, and serotonin) has been proposed as the neurobiological basis of behavioral symptoms of $\mathrm{AD}$, hence they are hypothesizing that altered reuptake of neurotransmitters by vesicular glutamate transporters (VGLUTs), excitatory amino acid transporters (EAATs), the vesicular acetylcholine transporter (VAChT), SERT or DAT. Examining protein and mRNA levels of these transporters in post-mortem prefrontal cortex from patients and matched non-AD controls, Chen et al. (2011) 
TABLE 10 | GABA transporter GAT1.

\begin{tabular}{|c|c|c|}
\hline Function/dysfunction & Findings & References \\
\hline GAT1 KO mice and ADHD & $\begin{array}{l}\text { Hyperactive behavior and memory dysfunctions in the MWM, also have low levels of attention and } \\
\text { increased impulsivity }\end{array}$ & Yang et al., 2013 \\
\hline GABA-transporter inhibitor & $\begin{array}{l}\text { Tiagabine, in the MWM, compared to saline treated rats, impaired learning during the acquisition trials. } \\
\text { And retrieval only at the probe trial }\end{array}$ & Schmitt and Hiemke, 2002 \\
\hline $\operatorname{GAT1}^{(-/-)} \mathrm{KO}$ mice & Impaired hippocampus-dependent learning and memory (MWM, PA) & Shi et al., 2012 \\
\hline $\begin{array}{l}\text { GABAergic immunotoxin: } \\
\text { GAT1-saporin (GAT1-SAP) }\end{array}$ & $\begin{array}{l}\text { Intraseptal impaired a delayed match to position task and extinction of avoidance without altering } \\
\text { acquisition of WMWM, active avoidance acquisition or open field behavior. Also, animals were slower } \\
\text { to update changes to previous contingencies }\end{array}$ & $\begin{array}{l}\text { Pang et al., 2011; but see } \\
\text { Köppen et al., } 2013\end{array}$ \\
\hline GAT1 $(+/-)$ mice & $\begin{array}{l}\text { Increased learning and memory, decreased anxiety-like behaviors, and highest synaptic plasticity } \\
\text { compared with wild-type and homozygous } \\
\text { GAT1(-/-) mice }\end{array}$ & Shi et al., 2012 \\
\hline
\end{tabular}

$A D H D$, attention deficit and hyperactivity disorder; KO, knock out; MWM, Morris water maze; PA, passive avoidance.

\section{TABLE 11 | Glutamate transporter 1 and markers.}

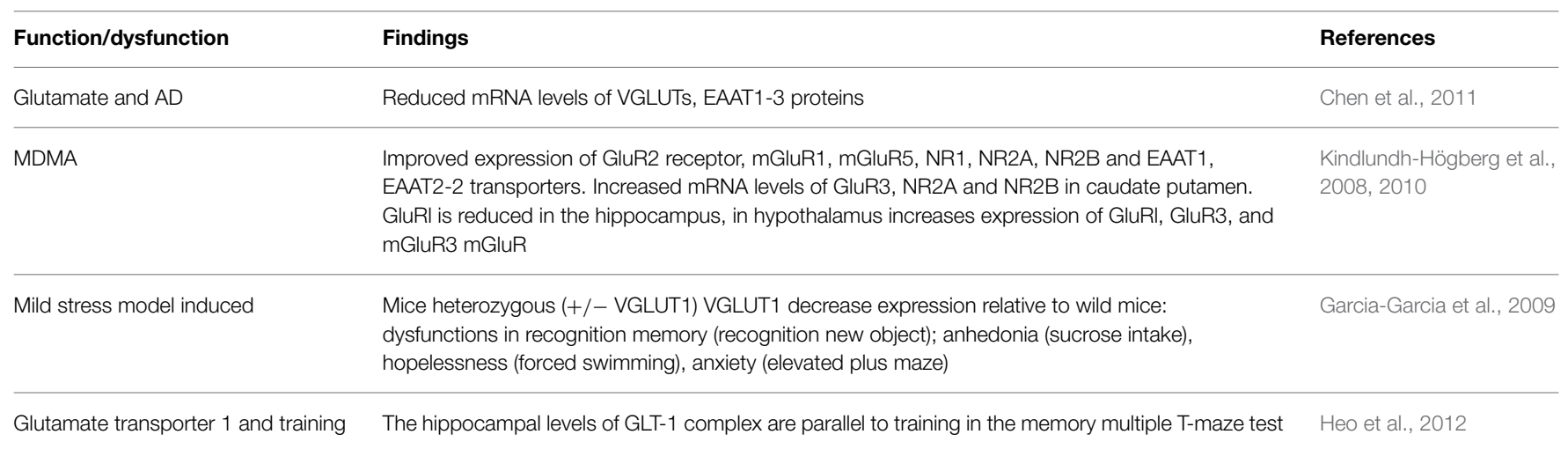

AD, Alzheimer's disease; VGLUTS, Vesicular glutamate transporters; MDMA, methylenedioxymethamphetamine.

found that protein and mRNA levels of VGLUTs, EAAT1-3, VAChT, and SERT are reduced in AD, without changing DAT (Table 11). Chen et al. (2011) conclude that the reduced VAChT expression could contribute to cholinergic deficit in $\mathrm{AD}$ and altered neurotransmitter transporters could contribute to the pathophysiology of $\mathrm{AD}$; which are potential targets for therapy (Chen et al., 2011).

Likewise, Kindlundh-Högberg et al. (2010) investigated the effect of intermittent 3,4-methylenedioxy-metamphetamine (MDMA; ecstasy) administration upon gene-transcript expression of the glutamate transporters (EAAT1, EAAT21, EAAT2-2), glutamate receptor subunits of AMPA (GluR1, GluR2, GluR3), glutamate receptor subunits of NMDA (NR1, NR2A, and NR2B), and metabotropic glutamate receptors (mGluR1, mGluR2, mGluR3, mGluR5); showing increased cortical expression of GluR2, mGluR1, mGluR5, NR1, NR2A, NR2B, EAAT1, and EAAT2-2 (Kindlundh-Högberg et al., 2010). In the caudate putamen, mRNA levels of GluR3, NR2A, and NR2B receptor subunits are increased; in contrast, GluR1 is reduced in the hippocampus but in the hypothalamus
GluR1, GluR3, mGluR1, and mGluR3 expression is increased (Kindlundh-Högberg et al., 2010; see also Carmona et al., 2009); concluding that repeated MDMA administration is associated with changes in gene-transcript expressions of glutamatergic NMDA and AMPA receptor subunits, metabotropic receptors and transporters in brain areas mediating learning and memory (Kindlundh-Högberg et al., 2010). In addition, decreased expression of vesicular glutamate transporter 1 (VGLUT1+/-) respect to wild-type (WT) mice occur with chronic mild stress (CMS)-induced, affecting several functions and impairing recognition memory. In addition, Heo et al. (2012) detect hippocampal glutamate transporter 1 (GLT-1) complex expression during training and memory in the Multiple T-maze.

\section{SERT}

Reichel et al. (2012) report that control rats spent more time interacting with the objects in the changed locations. In contrast, contingent or non-contingent methamphetamine (meth) disrupted object-in-place (OIP) task performance as seen by similar amounts of time spent with all objects, 
regardless of location. While only acute meth binge produced signs of neurotoxicity, both meth regimens decreased SERT in the perirhinal cortex and hippocampus. Only meth self-administration resulted in a selective decrease in NET. Meth-induced changes in SERT function in the OIP circuitry may underlie memory deficits independently of overt neurotoxic effects (Reichel et al., 2012). It should be noted that SERT is reduced in AD (Chen et al., 2011; Claeysen et al., 2015).

Parrott (2013) highlights that decreased SERT (hippocampus, parietal cortex, and prefrontal cortex expression) in abstinent Ecstasy/MDMA users is associated to dysfunctional declarative and prospective memory. Even the children of mothers who take Ecstasy/MDMA during pregnancy have psychomotor impairments (Parrott, 2013). In addition, Thomasius et al. (2006) report reduced SERT expression, which might be a transient effect of heavy ecstasy use, since it partially recovered as the users reduced their MDMA use; though this parameter may not necessarily be a valid indicator of the number or integrity of serotonergic neurons. Importantly, ex-ecstasy users' verbal memory show no sign of improvement even after over 2.5 years of abstinence and thus may represent persistent functional consequences of MDMA neurotoxicity; alternative causes such as pre-existing group differences cannot be excluded (Thomasius et al., 2006). In addition, $\mathrm{AD}$ and drugs of abuse like dmethamphetamine (METH) or MDMA have been associated to decrements in the SERT expression and memory deficits; thus supporting the notion that the SERT plays a key role in both normal and pathological states (e.g., Line et al., 2014). Particularly, the s allele of the polymorphic regulatory region of the SERT or 5-HTT gene promoter is associated with reduced 5-HTT expression and vulnerability to psychiatric disorders, including anxiety and depression. Moreover, the 1 allele increases 5-HTT expression and is generally considered protective (Line et al., 2014). However, Line et al. (2014) suggest that 5-HTT over-expression results in a reduced sensitivity to both positive and negative reinforcers, and produces some maladaptive effects, supporting recent suggestions that 1 allele homozygosity may

\section{TABLE 12 | Serotonin transporter SERT.}

\begin{tabular}{|c|c|c|}
\hline Function/dysfunction & Findings & References \\
\hline Methamphetamine & Memory deficits and decreased SERT function in perirhinal cortex and hippocampus & Reichel et al., 2012 \\
\hline MDMA (ecstasy) & $\begin{array}{l}\text { During abstinence memory deficits and decreased SERT in hippocampus, parietal cortex and } \\
\text { prefrontal cortex }\end{array}$ & Parrott, 2013 \\
\hline MDMA ex-users & Verbal memory dysfunction even after 2.5 years of abstinence & Thomasius et al., 2006 \\
\hline AD & Decreased SERT & Chen et al., 2011 \\
\hline 5-HT re-uptake inhibition & $\begin{array}{l}\text { In healthy individuals and aged transgenic AD mice model (APP/PS1 plaque-bearing mice), citalopram } \\
\text { decreased } A \beta \text { in brain interstitial fluid in a dose-dependent manner }\end{array}$ & Sheline et al., 2014a,b \\
\hline $\begin{array}{l}\text { 5-HT uptake inhibitor or SERT } \\
\text { KO mice }\end{array}$ & Pharmacological or genetic inactivation of the serotonin transporter improves reversal learning in mice & Brigman et al., 2010 \\
\hline Expression & $\begin{array}{l}\text { Overexpression of SERT reduces sensitivity to both positive and negative reinforcers evidence in CER } \\
\text { and the T-maze; this overexpression is maladaptive effects, suggesting that the homozygous allele/can } \\
\text { cause disabling psychiatric features }\end{array}$ & Line et al., 2014 \\
\hline Expression & Increased 5-HTT expression reduces negative cognitive bias for stimuli with uncertain outcomes & McHugh et al., 2015 \\
\hline
\end{tabular}

AD, Alzheimer's disease; MDMA, methylenedioxymethamphetamine; CER, conditioned emotional response.

\section{TABLE 13 | Dopamine transporter DAT.}

\begin{tabular}{|c|c|c|}
\hline Function/dysfuntion & Findings & References \\
\hline Cognition & $\begin{array}{l}\text { Variations in DAT1 influence the improvement of working memory in preschool } \\
\text { children after cognitive training }\end{array}$ & Söderqvist et al., 2012 \\
\hline Dopamine inhibition & $\begin{array}{l}\text { Modafinil is dopamine inhibitor can improve cognition in people with mental disorders } \\
\text { who use substances abuse }\end{array}$ & Mereu et al., 2013 \\
\hline Modulated DAT expression in animal model of ADHD & Improved selective spatial attention & Ruocco et al., 2014 \\
\hline
\end{tabular}

$A D H D$, attention deficit and hyperactivity disorder. 
be a potential risk factor for disabling psychiatric traits (Line et al., 2014). In contrast, increased 5-HTT expression reduces negative cognitive bias for stimuli with uncertain outcomes (McHugh et al., 2015). And Brigman et al. (2010) report that fluoxetine-treated $\mathrm{C} 57 \mathrm{BL} / 6 \mathrm{~J}$ mice made fewer errors than controls during the early phase of learning reversal when perseverative behavior is relatively high and 5-HTT null mice made fewer errors than controls in completing the reversal task (Table 12). And these authors suggest that inactivating 5-HTT improves reversal learning, which is relevant for the pathophysiology and treatment of neuropsychiatric disorders characterized by executive dysfunction (Brigman et al., 2010) and possibly post-traumatic stress disorder.

Certainly, SERT is providing useful information as neural marker and therapeutic target. For instance, Wallace et al. (2014) report that vortioxetine, a novel, multimodal-acting antidepressant, is a $5-\mathrm{HT}_{3}, 5-\mathrm{HT}_{7}$, and $5-\mathrm{HT}_{1 \mathrm{D}}$ receptor antagonist, a $5-\mathrm{HT}_{1 \mathrm{~B}}$ receptor partial agonist, a $5-\mathrm{HT}_{1 \mathrm{~A}}$ receptor agonist, and inhibits the 5-HT transporter. This drug changes the expression of multiple genes involved in neuronal plasticity by antidepressant treatment, which is associated with improved cognitive function and a reduction in depression-like behavior in middle-aged mice (Li et al., 2015c).

Hence, the SERT expression seems to be a reliable neural marker related to memory mechanisms, its alterations and potential treatment (Meneses, 2013). Resulting crucial determining the pharmacological, neural and molecular mechanisms associated to these changes and therapeutic targets. For instance, Sheline et al. (2014a) report that serotonin signaling suppresses generation of amyloid- $\beta(\mathrm{A} \beta)$ in-vitro and in animal models of $\mathrm{AD}$ and healthy individuals. In fact, in an aged transgenic $\mathrm{AD}$ mouse model the antidepressant citalopram (5-HT uptake inhibitor) in dose-dependent manner decreased $\mathrm{A} \beta$ in cerebrospinal fluid, suggesting $\mathrm{AD}$ prevention trials (Sheline et al., 2014a,b).

\section{DAT}

According with Mereu et al. (2013), modafinil (MOD) and its R-enantiomer (R-MOD) are used for narcolepsy and sleep disorders; and also employed, off-label used as cognitive

\section{References}

Abela, A. R., Dougherty, S. D., Fagen, E. D., Hill, C. J. R., and Chudasama, Y. (2013). Inhibitory control deficits in rats with ventral hippocampal lesions. Cereb. Cortex 23, 1396-1409. doi: 10.1093/cercor/ bhs121

Alabdali, A., Al-Ayadhi, L., and El-Ansary, A. (2014). Association of social and cognitive impairment and biomarkers in autism spectrum disorders. J. Neuroinflammation 11:4. doi: 10.1186/1742-2094-11-4

Aloyo, V. J., Berg, K. A., Spampinato, U., Clarke, W. P., and Harvey, J. A. (2009). Current status of inverse agonism at serotonin2A (5$\mathrm{HT}_{2 \mathrm{~A}}$ ) and 5- $\mathrm{HT}_{2 \mathrm{C}}$ receptors. Pharmacol. Ther. 121, 160-173. doi: 10.1016/j.pharmthera.2008.10.010

Atnip, G. W. (1977). Stimulus- and response-reinforcer contingencies in autoshaping, operant, classical, and omission training procedures in rats. J. Exp. Anal. Behav. 28, 59-69. doi: 10.1901/jeab.1977.28-59 enhancers in individuals with mental disorders, including substance abusers that demonstrate impaired cognitive function. Their mechanisms of action include inhibition of dopamine (DA) reuptake via the DAT in diverse brain areas (Mereu et al., 2013; Table 13). Importantly, memantine (MEM), a dual antagonist of NMDA and alpha7 receptors, is neuroprotector against MDMA in rats, and it also prevents MDMA effect on SERT functionality and METH effect on DAT (Escubedo et al., 2009). Moreover, Söderqvist et al. (2012) have noted that dopamine plays an important role not only in dysfunctional working memory (WM) but also for improving it, including variation in DAT1, improving WM and fluid intelligence in preschool-age children following cognitive training; concluding with the role of dopamine in determining cognitive plasticity (Söderqvist et al., 2012). Ruocco et al. (2014) report that $5-\mathrm{HT}_{7}$ receptor stimulation (low doses) was associated to among other findings reduced horizontal activity and (at higher dose) increased selective spatial attention, the DAT levels were decreased (low dose), and modulated expression of NMDA receptors.

It should be noted that, before the perspective of the absence of effective treatments for dysfunctional memory and regardless the mechanisms; environmental interventions and exercise (physical and cognitive) seem offer feasible approaches (e.g., Mora, 2013; Mo et al., 2015).

\section{Conclusions}

Of course if the above findings are replicated over time, across countries and in different experimental settings, they might provide insights about serotonin and other neurotransmission systems presenting convergent changes in diverse neural markers and signaling; thus, allowing the study of different brain functions and dysfunctions, including memory. Hence, diverse approaches might support the translatability of using neural markers and cerebral functions and dysfunctions (e.g., memory formation, $\mathrm{AD}, \mathrm{MCI}$ ). Likewise, hypothesis and theories (e.g., Borroto-Escuela et al., 2015) might provide appropriate limits and perspectives of the diversity of evidence. Certainly, at least, $5-\mathrm{HT}_{1 \mathrm{~A}}, 5-\mathrm{HT}_{4}, 5-\mathrm{HT}_{5}, 5-\mathrm{HT}_{6}$, and $5-\mathrm{HT}_{7}$ receptors as well as SERT seem to be useful as neural markers and therapeutic targets.

Aubert, Y., Allers, K. A., Sommer, B., de Kloet, E. R., Abbott, D. H., and Datson, N. A. (2013). Brain region-specific transcriptomic markers of serotonin$1 \mathrm{~A}$ receptor agonist action mediating sexual rejection and aggression in female marmoset monkeys. J. Sex Med. 10, 1461-1475. doi: 10.1111/jsm. 12131

Baas, J. M., and Heitland, I. (2014). The impact of cue learning, trait anxiety and genetic variation in the serotonin $1 \mathrm{~A}$ receptor on contextual fear. Int. J. Psychophysiol. doi: 10.1016/j.ijpsycho.2014.10.016. [Epub ahead of print].

Baba, S., Murai, T., Nakako, T., Enomoto, T., Ono, M., Shimizu, I., et al. (2015). The serotonin $5-\mathrm{HT}_{1 \mathrm{~A}}$ receptor agonist tandospirone improves executive function in common marmosets. Behav. Brain Res. 287, 120-126. doi: 10.1016/j.bbr.2015.03.025

Ballaz, S. J., Akil, H., and Watson, S. J. (2007). The 5-HT 7 receptor: role in novel object discrimination and relation to novelty-seeking behavior. Neuroscience 149, 192-202. doi: 10.1016/j.neuroscience.2007. 07.043 
Barlow, R. L., Alsiö, J., Jupp, B., Rabinovich, R., Shrestha, S., Roberts, A. C., et al. (2015). Markers of serotonergic function in the orbitofrontal cortex and dorsal raphé nucleus predict individual variation in spatial-discrimination serial reversal learning. Neuropsychopharmacology 40, 1619-1630. doi: 10.1038/ npp. 2014.335

Beaudet, G., Bouet, V., Jozet-Alves, C., Schumann-Bard, P., Dauphin, F., Paizanis, E., et al. (2015). Spatial memory deficit across aging: current insights of the role of 5-HT7 receptors. Front. Behav. Neurosci. 8:448. doi: 10.3389/fnbeh. 2014.00448

Benhamú, B., Martín-Fontecha, M., Vázquez-Villa, H., Pardo, L., and LópezRodríguez, M. L. (2014). Serotonin 5-HT6 receptor antagonists for the treatment of cognitive deficiency in Alzheimer's disease. J. Med. Chem. 57, 7160-7181. doi: 10.1021/jm5003952

Berry, J. A., Cervantes-Sandoval, I., Nicholas, E. P., and Davis, R. L. (2012). Dopamine is required for learning and forgetting in Drosophila. Neuron 74, 530-542. doi: 10.1016/j.neuron.2012.04.007

Blasi, G., Selvaggi, P., Fazio, L., Antonucci, L. A., Taurisano, P., Masellis, R., et al. (2015). Variation in Dopamine D2 and Serotonin 5-HT2A receptor genes is associated with working memory processing and response to treatment with antipsychotics. Neuropsychopharmacology 40, 1600-1608. doi: 10.1038/npp.2015.5

Blenau, W., and Baumann, A. (eds.). (2015). Serotonin Receptor Technologies, in Neuromethods, Vol. 95. New York, NY: Springer Science+Business Media.

Bockaert, J., Claeysen, S., Compan, V., and Dumuis, A. (2011). 5- $\mathrm{HT}_{4}$ receptors, a place in the sun: act two. Curr. Opin. Pharmacol. 11, 87-93. doi: 10.1016/j.coph.2011.01.012

Borg, J. (2008). Molecular imaging of the $5-\mathrm{HT}_{1 \mathrm{~A}}$ receptor in relation to human cognition. Behav. Brain Res. 195, 103-111. doi: 10.1016/j.bbr.2008.06.011

Borg, J., Henningsson, S., Saijo, T., Inoue, M., Bah, J., Westberg, L., et al. (2009). Serotonin transporter genotype is associated with cognitive performance but not regional $5-\mathrm{HT}_{1 \mathrm{~A}}$ receptor binding in humans. Int. J. Neuropsychopharmacol. 12, 783-792. doi: 10.1017/S1461145708009759

Borroto-Escuela, D. O., Agnati, L. F., Bechter, K., Jansson, A., Tarakanov, A. O., and Fuxe, K. (2015). The role of transmitter diffusion and flow versus extracellular vesicles in volume transmission in the brain neural-glial networks. Philos. Trans. R. Soc. Lond. B Biol. Sci. 370:20140183. doi: 10.1098/rstb.2014.0183

Brigman, J. L., Mathur, P., Harvey-White, J., Izquierdo, A., Saksida, L. M., Bussey, T. J., et al. (2010). Pharmacological or genetic inactivation of the serotonin transporter improves reversal learning in mice. Cereb. Cortex 20, 1955-1963. doi: 10.1093/cercor/bhp266

Brown, P. L., and Jenkins, H. M. (1968). Auto-shaping of the pigeon's key-peck. J. Exp. Anal. Behav. 11, 1-8. doi: 10.1901/jeab.1968.11-1

Buhot, M. C., Wolff, M., Benhassine, N., Costet, P., Hen, R., and Segu, L. (2003a). Spatial learning in the $5-\mathrm{HT}_{1 \mathrm{~B}}$ receptor knockout mouse: selective facilitation/impairment depending on the cognitive demand. Learn. Mem. 10, 466-477.

Buhot, M. C., Wolff, M., Savova, M., Malleret, G., Hen, R., and Segu, L. (2003b). Protective effect of $5-\mathrm{HT}_{1 \mathrm{~B}}$ receptor gene deletion on the age-related decline in spatial learning abilities in mice. Behav. Brain Res. 142, 135-142. doi: 10.1016/S0166-4328(02)00400-X

Bussey, T. J., Barch, D. M., and Baxter, M. G. (2013). Testing long-term memory in animal models of schizophrenia: suggestions from CNTRICS. Neurosci. Biobehav. Rev. 37, 2141-2148. doi: 10.1016/j.neubiorev.2013.06.005

Bussey, T. J., Everitt, B. J., and Robbins, T. W. (1997). Dissociable effects of cingulate and medial frontal cortex lesions on stimulus-reward learning using a novel Pavlovian autoshaping procedure for the rat: implications for the neurobiology of emotion. Behav. Neurosci. 111, 908-919. doi: 10.1037/07357044.111.5.908

Callaghan, B. L., Li, S., and Richardson, R. (2014). The elusive engram: what can infantile amnesia tell us about memory? Trends Neurosci. 37, 47-53. doi: 10.1016/j.tins.2013.10.007

Carmona, M., Muraib, K., Wanga, L., Roberts, A., and Pasquale, E. (2009). Glial ephrin-A3 regulates hippocampal dendritic spine morphology and glutamate transport. Proc. Natl. Acad. Sci. U.S.A. 106, 12524-12529. doi: 10.1073/pnas.0903328106

Cavallaro, S. (2008). Genomic analysis of serotonin receptors in learning and memory. Behav. Brain Res. 195, 2-6. doi: 10.1016/j.bbr.2007.12.003
Chen, K. H., Reese, E. A., Kim, H. W., Rapoport, S. I., and Rao, J. S. (2011). Disturbed neurotransmitter transporter expression in Alzheimer's disease brain. J. Alzheimers Dis. 26, 755-766. doi: 10.3233/JAD-2011110002

Chen, S., Cai, D., Pearce, K., Sun, P. Y., Roberts, A. C., and Glanzman, D. L. (2014). Reinstatement of long-term memory following erasure of its behavioral and synaptic expression in Aplysia. Elife 3:e03896. doi: 10.7554/eLife.03896

Ciranna, L., and Catania, M. V. (2014). 5- $\mathrm{HT}_{7}$ receptors as modulators of neuronal excitability, synaptic transmission and plasticity: physiological role and possible implications in autism spectrum disorders. Front. Cell. Neurosci. 8:250. doi: 10.3389/fncel.2014.00250

Claeysen, S., Bockaert, J., and Giannoni, P. (2015). Serotonin: a new hope in Alzheimer's disease? ACS Chem. Neurosci. doi: 10.1021/acschemneuro. 5b00135. [Epub ahead of print].

Cook, R. G., Geller, A. I., Zhang, G. R., and Gowda, R. (2004). Touch screenenhanced visual learning in rats. Behav. Res. Meth. Instrum. 36, 101-106. doi: 10.3758/BF03195555

Costa, L., Spatuzza, M., D’Antoni, S., Bonaccorso, C. M., Trovato, C., Musumeci, S. A., et al. (2012). Activation of $5-\mathrm{HT}_{7}$ serotonin receptors reverses metabotropic glutamate receptor-mediated synaptic plasticity in wild-type and Fmr1 knockout mice, a model of Fragile X syndrome. Biol. Psychiatry 72, 924-933. doi: 10.1016/j.biopsych.2012.06.008

Costall, B., and Naylor, R. J. (1992). Astra award lecture. The psychopharmacology of 5- $\mathrm{HT}_{3}$ receptors. Pharmacol. Toxicol. 71, 401-415. doi: 10.1111/j.16000773.1992.tb00570.x

Davis, R. (2010). Rac in the act of forgetting. Cell 140, 456-458. doi: 10.1016/j.cell.2010.02.004

Dayer, A. G., Jacobshagen, M., Chaumont-Dubel, S., and Marin, P. (2015). 5-HT6 receptor: a new player controlling the development of neural circuits. ACS Chem. Neurosci. doi: 10.1021/cn500326z. [Epub ahead of print].

Da Silva Costa-Aze, V., Quiedeville, A., Boulouard, M., and Dauphin, F. (2012). 5-HT6 receptor blockade differentially affects scopolamine-induced deficits of working memory, recognition memory and aversive learning in mice. Psychopharmacology (Berl). 222, 99-115. doi: 10.1007/s00213-011-2627-3

de Bruin, N. M., and Kruse, C. G. (2015). 5-HT6 receptor antagonists: potential efficacy for the treatment of cognitive impairment in Schizophrenia. Curr. Pharm. Des. [Epub ahead of print].

De Filippis, B., Chiodi, V., Adriani, W., Lacivita, E., Mallozzi, C., Leopoldo, M., et al. (2015). Long-1 lasting beneficial effects of central serotonin receptor 7 stimulation in female mice modeling Rett syndrome. Front. Behav. Neurosci. 9:86. doi: 10.3389/fnbeh.2015.00086

Delotterie, D. F., Mathis, C., Cassel, J. C., Rosenbrock, H., Dorner-Ciossek, C., and Marti, A. (2015). Touchscreen tasks in mice to demonstrate differences between hippocampal and striatal functions. Neurobiol. Learn. Mem. 120, 16-27. doi: 10.1016/j.nlm.2015.02.007

Di Pilato, P., Niso, M., Adriani, W., Romano, E., Travaglini, D., Berardi, F., et al. (2014). Selective agonists for serotonin 7 (5-HT7) receptor and their applications in preclinical models: an overview. Rev. Neurosci. 25, 401-415. doi: 10.1515/revneuro-2014-0009

Drago, A., Alboni, S., Brunello, N., De Ronchi, D., and Serretti, A. (2010). HTR1B as a risk profile maker in psychiatric disorders: a review through motivation and memory. Eur. J. Clin. Pharmacol. 66, 5-27. doi: 10.1007/s00228-0090724-6

Duewer, D., Currie, L., Reeder, D., Leigh, S., Liu, H., and Mudd, L. (1995). Interlaboratory comparison of autoradiographic DNA profiling measurements. 2. Measurement uncertainty and its propagation. Anal. Chem. 67, 1220-1231. doi: 10.1021/ac00103a013

Eglen, R. M., Wong, E. H., Dumuis, A., and Bockaert, J. (1995). Central 5-HT4 receptors. TIPS 16, 391-398.

Eriksson, T. M., Holst, S., Stan, T. L., Hager, T., Sjögren, B., Ogren, S. Ö., et al. (2012). 5- $\mathrm{HT}_{1 \mathrm{~A}}$ and $5-\mathrm{HT}_{7}$ receptor crosstalk in the regulation of emotional memory: implications for effects of selective serotonin reuptake inhibitors. Neuropharmacology 63, 1150-1160. doi: 10.1016/j.neuropharm.2012.06.061

Escubedo, E., Camarasa, J., Chipana, C., García-Ratés, S., and Pubill, D. (2009). Involvement of nicotinic receptors in methamphetamine- and MDMA-induced neurotoxicity: pharmacological implications. Int. Rev. Neurobiol. 88, 121-166. doi: 10.1016/S0074-7742(09)88006-9 
Eshkoor, S. A., Hamid, T. A., Mun, C. Y., and Ng, C. K. (2015). Document mild cognitive impairment and its management in older people. Clin. Interv. Aging 10, 687-693. doi: 10.2147/CIA.S73922

Eskenazi, D., Brodsky, M., and Neumaier, J. F. (2015). Deconstructing 5-HT6 receptor effects on striatal circuit function. Neuroscience 299, 97-106. doi: 10.1016/j.neuroscience.2015.04.046

Euston, D. R., Gruber, A. J., and McNaughton, B. L. (2012). The role of medial prefrontal cortex in memory and decision making. Neuron 76, 1057-1070. doi: 10.1016/j.neuron.2012.12.002

Fakhfouri, G., Mousavizadeh, K., Mehr, S. E., Dehpour, A. R., Zirak, M. R., Ghia, J. E., et al. (2014). From chemotherapy-induced emesis to neuroprotection: therapeutic opportunities for 5-HT3 receptor antagonists. Mol. Neurobiol. doi: 10.1007/s12035-014-8957-5. [Epub ahead of print].

Fink, L. H., Anastasio, N. C., Fox, R. G., Rice, K. C., Moeller, F. G., and Cunningham, K. A. (2015). Individual differences in impulsive action reflect variation in the cortical Serotonin 5-HT2A receptor system. Neuropsychopharmacology 40, 1957-1968. doi: 10.1038/npp.2015.46

Fioravanti, M., and Di Cesare, F. (1992). Forgetting curves in long-term memory: evidence for a multistage model of retention. Brain Cogn. 18, 116-124. doi: 10.1016/0278-2626(92)90073-U

Fitzpatrick, C. J., Gopalakrishnan, S., Cogan, E. S., Yager, L. M., Meyer, P. J., Lovic, V., et al. (2013). Variation in the form of Pavlovian conditioned approach behavior among outbred male Sprague-Dawley rats from different vendors and colonies: sign-tracking vs. goal-tracking. PLoS ONE 8:e75042. doi: 10.1371/journal.pone.0075042

Freret, T., Paizanis, E., Beaudet, G., Gusmao-Montaigne, A., Nee, G., Dauphin, F., et al. (2014). Modulation of 5- $\mathrm{HT}_{7}$ receptor: effect on object recognition performances in mice. Psychopharmacology 231, 393-400. doi: 10.1007/s00213013-3247-x

Gallistel, C. R., Balci, F., Freestone, D., Kheifets, A., and King, A. (2014). Automated, quantitative cognitive/behavioral screening of mice: for genetics, pharmacology, animal cognition and undergraduate instruction. J. Vis. Exp. e51047. doi: 10.3791/51047

Garcia-Alloza, M., Hirst, W. D., Chen, C. P., Lasheras, B., Francis, P. T., and Ramírez, M. J. (2004). Differential involvement of $5-\mathrm{HT}_{1 \mathrm{~B} / 1 \mathrm{D}}$ and $5-\mathrm{HT}_{6}$ receptors in cognitive and non-cognitive symptoms in Alzheimer's disease. Neuropsychopharmacology 29, 410-416. doi: 10.1038/sj.npp.1300330

Garcia-Garcia, A. L., Elizalde, N., Matrov, D., Harro, J., Wojcik, S. M., Venzala, E., et al. (2009). Increased vulnerability to depressive-like behavior of mice with decreased expression of VGLUT1. Biol. Psychiatry 66, 275-282. doi: 10.1016/j.biopsych.2009.02.027

Gasbarri, A., Cifariello, A., Pompili, A., and Meneses, A. (2008). Effect of 5$\mathrm{HT}_{7}$ antagonist SB-269970 in the modulation of working and reference memory in the rat. Behav. Brain Res. 195, 164-170. doi: 10.1016/j.bbr.2007. 12.020

Gasbarri, A., and Pompili, A. (2014). Serotonergic 5- $\mathrm{HT}_{7}$ receptors and cognition. Rev. Neurosci. 25, 311-323. doi: 10.1515/revneuro-2013-0066

Glikmann-Johnston, Y., Saling, M. M., Chen, J., O'Keefe, G., Gong, S., TochonDanguy, $\mathrm{H}$., et al. (2015). Hippocampal 5- $\mathrm{HT}_{1 \mathrm{~A}}$ receptor binding is related to object-location memory in humans. Brain Struct. Funct. 220, 559-570. doi: 10.1007/s00429-013-0675-7

Gonzalez, R., Chávez-Pascacio, K., and Meneses, A. (2013). Role of 5-HT $\mathrm{HA}_{5 \mathrm{~A}}$ receptors in the consolidation of memory. Behav. Brain Res. 252, 246-251. doi: 10.1016/j.bbr.2013.05.051

Guglielmi, V., Bizzarro, A., Valenza, A., Lauria, A., Tiziano, F., Lomastro, R., et al. (2015). A Functional $5 \mathrm{HT}_{2 \mathrm{~A}}$ receptor polymorphism (HIS452TYR) and memory performances in Alzheimer's disease. Int. J. Neurosci. 22, 1-16. doi: 10.3109/00207454.2015.1045976

Guseva, D., Wirth, A., and Ponimaskin, E. (2014). Cellular mechanisms of the $5-\mathrm{HT}_{7}$ receptor-mediated signaling. Front. Behav. Neurosci. 8:306. doi: $10.3389 /$ fnbeh.2014.00306

Gyurko, M. D., Stetak, A., Soti, C., and Csermely, P. (2015). Multitarget network strategies to influence memory and forgetting: the ras/mapk pathway as a novel option. Mini Rev. Med. Chem. 15, 696-704. doi: 10.2174/1389557515666150219144336

Ha, C. M., Park, D., Kim, Y., Na, M., Panda, S., Won, S., et al. (2015). SNX14 is a bifunctional negative regulator for neuronal 5-HT6 receptor signaling. J. Cell Sci. 128, 1848-1861. doi: $10.1242 /$ jcs. 169581
Haahr, M. E., Fisher, P., Holst, K., Madsen, K., Jensen, C. G., Marner, L., et al. (2013). The 5- $\mathrm{HT}_{4}$ receptor levels in hippocampus correlates inversely with memory test performance in humans. Hum. Brain Mapp. 34, 3066-3074. doi: $10.1002 / \mathrm{hbm} .22123$

Hardt, O., Nader, K., and Nadel, L. (2013). Decay happens: the role of active forgetting in memory. Trends Cogn. Sci. 17, 111-120. doi: 10.1016/j.tics.2013.01.001

Hashimoto, K. (2015). Tropisetron and its targets in Alzheimer's disease. Expert Opin. Ther. Targets 19, 1-5. doi: 10.1517/14728222.2014.983901

Hautzel, H., Müller, H. W., Herzog, H., and Grandt, R. (2011). Cognitioninduced modulation of serotonin in the orbitofrontal cortex: a controlled cross-over PET study of a delayed match-to-sample task using the 5$\mathrm{HT}_{2 a}$ receptor antagonist $\left[{ }^{18} \mathrm{~F}\right]$ altanserin. Neuroimage 58, 905-911. doi: 10.1016/j.neuroimage.2011.06.009

Heo, S., Jung, G., Beuk, T., Höger, H., and Lubec, G. (2012). Hippocampal glutamate transporter 1 (GLT-1) complex levels are paralleling memory training in the multiple T-maze in C57BL/6J mice. Brain Struct. Funct. 217, 363-378. doi: 10.1007/s00429-011-0362-5

Holland, P. C., Asem, J. S., Galvin, C. P., Keeney, C. H., Hsu, M., Miller, A., et al. (2014). Blocking in autoshaped lever-pressing procedures with rats. Learn. Behav. 42, 1-21. doi: 10.3758/s13420-013-0120-z

Horisawa, T., Nishikawa, H., Toma, S., Ikeda, A., Horiguchi, M., Ono, M., et al. (2013). The role of 5- $\mathrm{HT}_{7}$ receptor antagonism in the amelioration of MK-801induced learning and memory deficits by the novel atypical antipsychotic drug lurasidone. Behav. Brain Res. 244, 66-69. doi: 10.1016/j.bbr.2013.01.026

Horner, A. E., Heath, C. J., Hvoslef-Eide, M., Kent, B. A., Kim, C. H., Nilsson, S. R., et al. (2013). The touchscreen operant platform for testing learning and memory in rats and mice. Nat. Protoc. 8, 1961-1984. doi: 10.1038/nprot.2013.122

Hostetler, G., Dunn, D., McKenna, B. A., Kopec, K., and Chatterjee, S. (2014). In search of potent $5-\mathrm{HT}_{6}$ receptor inverse agonists. Chem. Biol. Drug Design 83, 666-669. doi: 10.1111/cbdd.12279

Hoyer, D., Clarke, D. E., Fozard, J. R., Hartig, P. R., Martin, G. R., Mylecharane, E. J., et al. (1994). International union of pharmacology classification of receptors for 5-hydroxytryptamine (Serotonin). Pharmacol. Rev. 46, 157-203.

$\mathrm{Hu}$, J., and Quick, M. (2008). Substrate-mediated regulation of $\gamma$-aminobutyric acid transporter 1 in rat brain. Neuropharmacology 54, 309-318. doi: 10.1016/j.neuropharm.2007.09.013

Huerta-Rivas, A., Pérez-García, G., González-Espinosa, C., and Meneses, A. (2010). Time-course of $5-\mathrm{HT}_{6}$ receptor mRNA expression during memory consolidation and amnesia. Neurobiol. Learn. Mem. 93, 99-110. doi: 10.1016/j.nlm.2009.08.009

Hupbach, A. (2013). When forgetting preserves memory. Front. Psychol. 4:32. doi: 10.3389/fpsyg.2013.00032

Kaku, M., Yamada, K., and Ichitani, Y. (2013). Can rats control previously acquired spatial information? Evidence of "directed forgetting" phenomenon in delay-interposed radial maze behavior. Behav. Brain Res. 248, 1-6. doi: 10.1016/j.bbr.2013.03.030

Kandel, E. R. (2001). The molecular biology of memory storage: a dialogue between genes and synapses. Science 294, 1030-1038. doi: 10.1126/science. 1067020

Karimi, B., Hafidzi, M. N., Panandam, J. M., and Fuzina, N. H. (2013). Comparison of effect of sex hormone manipulation during neonatal period, on mRNA expression of Slc9a4, Nr3c2, Htr5b and Mas1 in hippocampus and frontal cortex of male and female rats. J. Biol. Regul. Homeost. Agents 27, 869-874.

Kindlundh-Högberg, A. M., Blomqvist, A., Malki, R., and Schiöth, H. B. (2008). Extensive neuroadaptive changes in cortical gene-transcript expressions of the glutamate system in response to repeated intermittent MDMA administration in adolescent rats. BMC Neurosci. 9:39. doi: 10.1186/1471-2202-9-39

Kindlundh-Högberg, A. M., Pickering, C., Wicher, G., Hobér, D., Schiöth, H. B., and Fex Svenningsen, A. (2010). MDMA (Ecstasy) decreases the number of neurons and stem cells in embryonic cortical cultures. Cell. Mol. Neurobiol. 30, 13-21. doi: 10.1007/s10571-009-9426-y

King, M. V., Marsden, C. A., Fone, K. C. (2008). A role for the 5-HT1A, 5-HT4 and 5-HT6 receptors in learning and memory. Trends Pharmacol. Sci. 29, 482-492. doi: 10.1016/j.tips.2008.07.001

Kitamura, S., Yasuno, F., Inoue, M., Kosaka, J., Kiuchi, K., Matsuoka, K., et al. (2014). Increased binding of 5-HT1A receptors in a dissociative 
amnesic patient after the recovery process. Psychiatry Res. 224, 67-71. doi: 10.1016/j.pscychresns.2014.07.001

Kondo, M., Nakamura, Y., Ishida, Y., and Shimada, S. (2014). The 5-HT3 receptor is essential for exercise-induced hippocampal neurogenesis and antidepressant effects. Mol. Psychiatry doi: 10.1038/mp.2014.153. [Epub ahead of print].

Köppen, J. R., Winter, S. S., Stuebing, S. L., Cheatwood, J. L., and Wallace, D. G. (2013). Infusion of GAT1-saporin into the medial septum/vertical limb of the diagonal band disrupts self-movement cue processing and spares mnemonic function. Brain Struct. Funct. 218, 1099-1114. doi: 10.1007/s00429-012-0449-7

Kozuska, J. L., Paulsen, I. M., Belfield, W. J., Martin, I. L., Cole, D. J., Holt, A., et al. (2014). Impact of intracellular domain flexibility upon properties of activated human 5-HT3 receptors. Br. J. Pharmacol. 171, 1617-1628. doi: 10.1111/bph.12536

Krynetskiy, E., Krynetskaia, N., Rihawi, D., Wieczerzak, K., Ciummo, V., and Walker, E. (2013). Establishing a model for assessing DNA damage in murine brain cells as a molecular marker of chemotherapy-associated cognitive impairment. Life Sci. 93, 605-610. doi: 10.1016/j.lfs.2013. 03.013

Lau, T., Proissl, V., Ziegler, J., and Schloss, P. (2015). Visualization of neurotransmitter uptake and release in serotonergic neurons. J. Neurosci. Methods 241, 10-17. doi: 10.1016/j.jneumeth.2014.12.009

Lecoutey, C., Hedou, D., Freret, T., Giannoni, P., Gaven, F., Since, M., et al. (2014). Design of donecopride, a dual serotonin subtype 4 receptor agonist/acetylcholinesterase inhibitor with potential interest for Alzheimer's disease treatment. Proc. Natl. Acad. Sci. U.S.A. 111, E3825-E3830. doi: 10.1073/pnas.1410315111

Leger, M., Paizanis, E., Dzahini, K., Quiedeville, A., Bouet, V., Cassel, J. C., et al. (2014). Environmental enrichment duration differentially affects behavior and neuroplasticity in adult mice. Cereb. Cortex. doi: 10.1093/cercor/bhu119. [Epub ahead of print].

Leiser, S. C., Li, Y., Pehrson, A. L., Dale, E., Smagin, G., and Sanchez, C. (2015). Serotonergic regulation of prefrontal cortical circuitries involved in cognitive processing: a review of individual 5-HT receptor mechanisms and concerted effects of 5-HT receptors exemplified by the multimodal antidepressant vortioxetine. ACS Chem. Neurosci. doi: 10.1021/cn500340j. [Epub ahead of print].

Lesaint, F., Sigaud, O., Flagel, S. B., Robinson, T. E., and Khamassi, M. (2014). Modelling individual differences in the form of Pavlovian conditioned approach responses: a dual learning systems approach with factored representations. PLoS Comput. Biol. 10:e1003466. doi: 10.1371/journal.pcbi.1003466

Li, H. J., Peng, R. Y., Wang, C. Z., Qiao, S. M., Yong, Z., Gao, Y. B., et al. (2015b). Alterations of cognitive function and 5-HT system in rats after long term microwave exposure. Physiol. Behav. 140, 236-246. doi: 10.1016/j.physbeh.2014.12.039

Li, L. B., Zhang, L., Sun, Y. N., Han, L. N., Wu, Z. H., Zhang, Q. J., et al. (2015a). Activation of serotonin $_{2 A}$ receptors in the medial septum-diagonal band of Broca complex enhanced working memory in the hemiparkinsonian rats. Neuropharmacology 91, 23-33. doi: 10.1016/j.neuropharm.2014. 11.025

Li, S., and Richardson, R. (2013). Traces of memory: reacquisition of fear following forgetting is NMDAr-independent. Learn. Mem. 20, 174-182. doi: 10.1101/lm.029504.112

Li, Y., Abdourahman, A., Tamm, J. A., Pehrson, A. L., Sánchez, C., and Gulinello, M. (2015c). Reversal of age-associated cognitive deficits is accompanied by increased plasticity-related gene expression after chronic antidepressant administration in middle-aged mice. Pharmacol. Biochem. Behav. 135, 70-82. doi: $10.1016 /$ j.pbb.2015.05.013

Lim, C. S., Hoang, E. T., Viar, K. E., Stornetta, R. L., Scott, M. M., and Zhu, J. J. (2014). Pharmacological rescue of Ras signaling, GluA1-dependent synaptic plasticity, and learning deficits in a fragile X model. Genes Dev. 28, 273-289. doi: $10.1101 /$ gad.232470.113

Lindner, M. D., Hodges, D. B. Jr., Hogan, J. B., Orie, A. F., Corsa, J. A., Barten, D. M., et al. (2003). An assessment of the effects of serotonin 6 (5-HT6) receptor antagonists in rodent models of learning. J. Pharmacol. Exp. Ther. 307, 682-691. doi: 10.1124/jpet.103.056002

Line, S. J., Barkus, C., Rawlings, N., Jennings, K., McHugh, S., Sharp, T., et al. (2014). Reduced sensitivity to both positive and negative reinforcement in mice over-expressing the 5-hydroxytryptamine transporter. Eur. J. Neurosci. 40, 3735-3745. doi: 10.1111/ejn.12744

Ludowiq, E., Möller, J., Bien, C., Münte, T., Elger, C., and Rosburg, T. (2010). Active suppression in the mediotemporal lobe during directed forgetting. Neurobiol. Learn. Mem. 93, 352-361. doi: 10.1016/j.nlm.2009.12.001

Luna-Munguía, H., Manuel-Apolinar, L., Rocha, L., and Meneses, A. (2005). 5 $\mathrm{HT}_{1 \mathrm{~A}}$ receptor expression during memory formation. Psychopharmacology (Berl). 181, 309-318. doi: 10.1007/s00213-005-2240-4

Lynch, M. A. (2004). Long term potentiation. Physiol. Rev. 84, 87-136. doi: 10.1152/physrev.00014.2003

Madsen, K., Neumann, W. J., Holst, K., Marner, L., Haahr, M. T., Lehel, S., et al. (2011). Cerebral serotonin 4 receptors and amyloid- $\beta$ in early Alzheimer's disease. J. Alzheimers Dis. 26, 457-466. doi: 10.3233/JAD-2011-110056

Mansuy, I. M. (2005). Forgetting: theories and potential mechanisms. Med. Sci. 21, 83-88. doi: 10.1051/medsci/200521183

Manuel-Apolinar, L., Rocha, L., Pascoe, D., Castillo, E., Castillo, C., and Meneses, A. (2005). Modifications of $5-\mathrm{HT}_{4}$ receptor expression in rat brain during memory consolidation. Brain Res. 1042, 73-81. doi: 10.1016/j.brainres.2005.02.020

Marchetti, E., Jacquet, M., Escoffier, G., Miglioratti, M., Dumuis, A., Bockaert, J., et al. (2011). Enhancement of reference memory in aged rats by specific activation of $5-\mathrm{HT}_{4}$ receptors using an olfactory associative discrimination task. Brain Res. 1405, 49-56. doi: 10.1016/j.brainres.2011.06.020

Marcos, B., García-Alloza, M., Gil-Bea, F. J., Chuang, T. T., Francis, P. T., Chen, C. P., et al. (2008). Involvement of an altered $5-\mathrm{HT}_{6}$ receptor functions in behavioral symptoms of Alzheimer's disease. J. Alzheimers Dis. 14, 43-50.

Marcus, E. (2014). Credibility and reproducibility. Cell 159, 965-966. doi: 10.1016/j.cell.2014.11.016

Marin, P., Becamel, C., Dumuis, A., and Bockaert, J. (2012). 5-HT receptorassociated protein networks: new targets for drug discovery in psychiatric disorders? J. Curr. Drug Targets 13, 28-52. doi: 10.2174/1389450127988 68498

Markou, A., Salamone, J. D., Bussey, T. J., Mar, A. C., Brunner, D., Gilmour, G., et al. (2013). Measuring reinforcement learning and motivation constructs in experimental animals: relevance to the negative symptoms of schizophrenia. Neurosci. Biobehav. Rev. 37, 2149-2165. doi: 10.1016/j.neubiorev.2013.08.007

McConathy, J., and Sheline, Y. I. (2015). Imaging biomarkers associated with cognitive decline: a review. Biol. Psychiatry 77, 685-692. doi 10.1016/j.biopsych.2014.08.024

McCorvy, J. D., and Roth, B. L. (2015). Structure and function of serotonin G protein-coupled receptors. Pharmacol. Ther. 150, 129-142. doi: 10.1016/j. pharmthera.2015.01.009

McGaugh, J. L. (2013). Making lasting memories: remembering the significant. Proc. Natl. Acad. Sci. U.S.A. 110, 10402-10407. doi: 10.1073/pnas.1301 209110

McHugh, S. B., Barkus, C., Lima, J., Glover, L. R., Sharp, T., and Bannerman, D. M. (2015). SERT and uncertainty: serotonin transporter expression influences information processing biases for ambiguous aversive cues in mice. Genes Brain Behav. 14, 330-336. doi: 10.1111/gbb.12215

Ménard, C., Gaudreau, P., and Quirion, R. (2015). "Signaling pathways relevant to cognition-enhancing drug targets," in Cognitive Enhancement, Handbook of Experimental Pharmacology, eds K. M. Kantak and J. G. Wettstein (Heidelberg; New York; Dordrecht; London: Springer Cham), 59-98.

Ménard, C., and Quirion, R. (2012). Successful cognitive aging in rats: a role for mGluR5 glutamate receptors, Homer 1 proteins and downstream signaling pathways. PLoS ONE 7:e28666. doi: 10.1371/journal.pone.0028666

Meneses, A. (1999). 5-HT system and cognition. Neurosci. Biobehav. Rev. 23, 1111-1125. doi: 10.1016/S0149-7634(99)00067-6

Meneses, A. (2001). Could the $5-\mathrm{HT}_{1 \mathrm{~B}}$ receptor inverse agonism affect learning consolidation? Neurosci. Biobehav. Rev. 25, 193-201. doi: 10.1016/S01497634(01)00007-0

Meneses, A. (2013). 5-HT systems: emergent targets for memory formation and memory alterations. Rev. Neurosci. 24, 629-664. doi: 10.1515/revneuro2013-0026

Meneses, A. (2014). "Neurotransmitters and memory: cholinergic, glutamatergic, gabaergic, dopaminergic, serotonergic, signaling, and memory," in Identification of Neural Markers Accompanying Memory, ed A. Meneses (San Diego, CA: Elsevier), 5-45. 
Meneses, A., and Liy-Salmeron, G. (2012). Serotonin and emotion, learning and memory. Rev. Neurosci. 23, 543-553. doi: 10.1515/revneuro-2012-0060

Meneses, A., and Perez-Garcia, G. (2007). 5- $\mathrm{HT}_{1 \mathrm{~A}}$ receptors and memory. Neurosci. Biobehav. Rev. 31, 705-727. doi: 10.1016/j.neubiorev.2007.02.001

Meneses, A., Perez-Garcia, G., Liy-Salmeron, G., Ponce-López, T., Lacivita, E., and Leopoldo, M. (2015). 5- $\mathrm{HT}_{7}$ receptor activation: procognitive and antiamnesic effects. Psychopharmacology (Berl). 232, 595-603. doi: 10.1007/s00213-0143693-0

Meneses, A., Pérez-García, G., Ponce-Lopez, T., and Castillo, C. (2011c). 5$\mathrm{HT}_{6}$ receptor memory and amnesia: behavioral pharmacology-learning and memory processes. Int. Rev. Neurobiol. 96, 27-47. doi: 10.1016/B978-0-12385902-0.00002-4

Meneses, A., Perez-Garcia, G., Ponce-Lopez, T., Tellez, R., and Castillo, C. (2011b). Serotonin transporter and memory. Neuropharmacology 61, 355-363. doi: 10.1016/j.neuropharm.2011.01.018

Meneses, A., Perez-Garcia, G., Ponce-Lopez, T., Tellez, R., Gallegos-Cari, A., and Castillo, C. (2011a). Spontaneously hypertensive rat (SHR) as an animal model for ADHD: a short overview. Rev. Neurosci. 22, 365-371. doi: 10.1515/rns.2011.024

Meneses, A., and Tellez, R. (2015). “Autoshaping memory formation and retention loss: are serotonin and other neurotransmitter transporters involved?" in Serotonin Receptor Technologies, Neuromethods, Vol. 95, eds W. Blenau and A. Baumann (New York, NY: Springer Science+Business Media), 125-149.

Mereu, M., Bonci, A., Newman, A. H., and Tanda, G. (2013). The neurobiology of modafinil as an enhancer of cognitive performance and a potential treatment for substance use disorders. Psychopharmacology (Berl). 229, 415-434. doi: 10.1007/s00213-013-3232-4

Meyer-Lindenberg, A., Murphy, D., Rolls, E., Saletu, B., Spedding, M., Sweeney, J., et al. (2012). Cognitive dysfunction in psychiatric disorders: characteristics, causes and the quest for improved therapy. Nat. Rev. Drug Discov. 1, 141-168. doi: $10.1038 / \mathrm{nrd} 3628$

Millan, M. J., Agid, Y., Brune, M., Bullmore, E. T., Carter, C. S., Clayton, N. S., et al. (2012). Cognitive dysfunction in psychiatric disorders: characteristics, causes and the quest for improved therapy. Nat. Rev. Drug. Discov. 11, 141-168. doi: $10.1038 / \operatorname{nrd} 3628$

Millan, M. J., Agid, Y., Brüne, M., Bullmore, E. T., Carter, C. S., Clayton, N. S., et al. (2014). The clinical use of cerebrospinal fluid biomarker testing for Alzheimer's disease diagnosis: a consensus paper from the Alzheimer's biomarkers standardization initiative. Alzheimers Dement. 10, 808-817. doi: 10.1016/j.jalz.2014.03.003

Mo, C., Hannan, A. J., and Renoir, T. (2015). Environmental factors as modulators of neurodegeneration: insights from gene-environment interactions in Huntington's disease. Neurosci. Biobehav. Rev. 52, 178-192. doi: 10.1016/j.neubiorev.2015.03.003

Monje, F. J., Divisch, I., Demit, M., Lubec, G., and Pollak, D. D. (2013). Flotillin-1 is an evolutionary-conserved memory-related protein up-regulated in implicit and explicit learning paradigms. Ann. Med. 45, 301-307. doi: $10.3109 / 07853890.2013 .770637$

Mora, F. (2013). Successful brain aging: plasticity, environmental enrichment, and lifestyle. Dialogues Clin. Neurosci. 15, 45-52.

Morton, R. A., Baptista-Hon, D. T., Hales, T. G., and Lovinger, D. M. (2015). Agonist- and antagonist-induced up-regulation of surface 5-HT3A receptors. Br. J. Pharmacol. doi: 10.1111/bph.13197. [Epub ahead of print].

Muenchhoff, J., Poljak, A., Song, F., Raftery, M., Brodaty, H., Duncan, M., et al. (2015). Plasma protein profiling of mild cognitive impairment and Alzheimer's disease across two independent cohorts. J. Alzheimers Dis. 43, 1355-1373.

Müller, C. P., and Homberg, J. R. (2015). The role of serotonin in drug use and addiction. Behav. Brain Res. 277, 146-192. doi: 10.1016/j.bbr.2014. 04.007

Myer, J. S., and Hull, J. H. (1974). Autoshaping and instrumental learning in the rat. J. Comp. Physiol. Psychol. 86, 724-729. doi: 10.1037/h0036165

Myhrer, T. (2003). Neurotransmitter systems involved in learning and memory in the rat: a meta-analysis based on studies of four behavioral tasks. Brain Res. Rev. 41, 268-287. doi: 10.1016/S0165-0173(02)00268-0

Nasehi, M., Jamshidi-Mehr, M., Khakpai, F., and Zarrindast, M. R. (2014a).

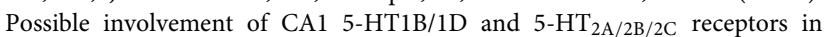
harmaline-induced amnesia. Pharmacol. Biochem. Behav. 125, 70-77. doi: 10.1016/j.pbb.2014.08.007
Nasehi, M., Tabatabaie, M., Khakpai, F., and Zarrindast, M. (2014b). The effects of CA1 5HT4 receptors in MK801-induced amnesia and hyperlocomotion. Neurosci. Lett. 587C, 73-78. doi: 10.1016/j.neulet.2014.12.019

Nikiforuk, A. (2015). Targeting the Serotonin 5-HT7 receptor in the search for treatments for CNS disorders: rationale and progress to date. CNS Drugs 29, 265-275. doi: 10.1007/s40263-015-0236-0

Nikiforuk, A., Kos, T., Fijał, K., Hołuj, M., Rafa, D., and Popik, P. (2013). Effects of the selective $5-\mathrm{HT}_{7}$ receptor antagonist SB-269970 and amisulpride on ketamine-induced schizophrenia-like deficits in rats. PLoS ONE 8:e66695. doi: 10.1371/journal.pone.0066695

Oscos, A., Martinez, J. L. Jr., and McGaugh, J. L. (1988). Effects of posttraining d-amphetamine on acquisition of an appetitive autoshaped lever press response in rats. Psychopharmacology (Berl) 95, 132-134. doi: 10.1007/ BF00212781

Pang, K. C., Jiao, X., Sinha, S., Beck, K. D., and Servatius, R. J. (2011). Damage of GABAergic neurons in the medial septum impairs spatial working memory and extinction of active avoidance: effects on proactive interference. Hippocampus 21, 835-846. doi: 10.1002/hipo.20799

Papenberg, G., Bäckman, L., Nagel, I. E., Nietfeld, W., Schröder, J., Bertram, L., et al. (2013). Dopaminergic gene polymorphisms affect long-term forgetting in old age: further support for the magnification hypothesis. J. Cogn. Neurosci. 25, 571-579. doi: 10.1162/jocn_a_00359

Parrott, A. C. (2013). MDMA, serotonergic neurotoxicity, and the diverse functional deficits of recreational 'Ecstasy' users. Neurosci. Biobehav. Rev. 37, 1466-1484. doi: 10.1016/j.neubiorev.2013.04.016

Patton, W. (1995). Biologist's perspective on analytical imaging systems as applied to protein gel electrophoresis. J. Chromatogr. A 698, 55-87. doi: 10.1016/00219673(94)00987-K

Peele, D. B., and Vincent, A. (1989). Strategies for assessing learning and memory, 1978-1987: a comparison of behavioral toxicology, psychopharmacology, and neurobiology. Neurosci. Biobehav. Rev. 13, 317-322. doi: 10.1016/S01497634(89)80068-5

Peñas-Cazorla, R., and Vilaró, M. T. (2014). Serotonin 5-HT4 receptors and forebrain cholinergic system: receptor expression in identified cell populations. Brain Struct. Funct. doi: 10.1007/s00429-014-0864-z. [Epub ahead of print].

Pérez-García, G., González-Espinosa, C., and Meneses, A. (2006). An mRNA expression analysis of stimulation and blockade of $5-\mathrm{HT}_{7}$ receptors during memory consolidation. Behav. Brain Res. 169, 83-92. doi: 10.1016/j.bbr.2005.12.013

Perez-Garcia, G., and Meneses, A. (2009). Memory time-course: mRNA $5-\mathrm{HT}_{1 \mathrm{~A}}$ and $5-\mathrm{HT}_{7}$ receptors. Behav. Brain Res. 202, 102-113. doi: 10.1016/j.bbr.2009.03.027

Pérez-García, G., and Meneses, A. (2008). Ex-vivo study of 5-HT $1 \mathrm{~A}$ and 5$\mathrm{HT}_{7}$ receptor agonists and antagonists on cAMP accumulation during memory formation and amnesia. Behav. Brain Res. 195, 139-146. doi: 10.1016/j.bbr.2008.07.033

Perez-García, G. S., and Meneses, A. (2005). Effects of the potential 5-HT 7 receptor agonist AS 19 in an autoshaping learning task. Behav. Brain Res. 163, 136-140. doi: 10.1016/j.bbr.2005.04.014

Pithers, R. T. (1985). The roles of event contingencies and reinforcement in human autoshaping and omission responding. Learn. Motiv. 16, 210-237. doi: 10.1016/0023-9690(85)90013-X

Pittalà, V., Siracusa, M. A., Salerno, L., Romeo, G., Modica, M. N., Madjid, N., et al. (2015). Analysis of mechanisms for memory enhancement using novel and potent 5-HT1A receptor ligands. Eur. J. Neuropsychopharmacol. doi: 10.1016/j. euroneuro.2015.04.017. [Epub ahead of print].

Pitychoutis, P. M., Belmer, A., Moutkine, I., Adrien, J., and Maroteaux, L. (2015). Mice lacking the serotonin Htr2B receptor gene present an antipsychoticsensitive schizophrenic-like phenotype. Neuropsychopharmacology. doi: 10.1038/npp.2015.126. [Epub ahead of print].

Puig, M. V., and Gulledge, A. T. (2011). Serotonin and prefrontal cortex function: neurons, networks, and circuits. Mol. Neurobiol. 44, 449-464. doi: 10.1007/s12035-011-8214-0

Ramirez, M. J., Lai, M. K., Tordera, R. M., and Francis, P. T. (2014). Serotonergic therapies for cognitive symptoms in Alzheimer's disease: rationale and current status. Drugs 74, 729-736. doi: 10.1007/s40265-014-0217-5

Reichel, C. M., Ramsey, L. A., Schwendt, M., McGinty, J. F., and See, R. E. (2012). Methamphetamine-induced changes in the object recognition memory 
circuit. Neuropharmacology 62, 1119-1126. doi: 10.1016/j.neuropharm.2011. 11.003

Restivo, L., Roman, F., Dumuis, A., Bockaert, J., Marchetti, E., and AmmassariTeule, M. (2008). The promnesic effect of G-protein-coupled 5- $\mathrm{HT}_{4}$ receptors activation is mediated by a potentiation of learning-induced spine growth in the mouse hippocampus. Neuropsychopharmacology 33, 2427-2434. doi: 10.1038/sj.npp.1301644

Rodríguez, J. J., Noristani, H. N., and Verkhratsky, A. (2012). The serotonergic system in ageing and Alzheimer's disease. Prog. Neurobiol. 99, 15-41. doi: 10.1016/j.pneurobio.2012.06.010

Rodriguez, J. S., Boctor, S. Y., Phelix, C. F., and Martinez, J. L. Jr. (2008). Differences in performance between Sprague-Dawley and Fischer 344 rats in positive reinforcement tasks. Pharmacol. Biochem. Behav. 89, 17-22. doi: 10.1016/j.pbb.2007.10.017

Rojas, P. S., Neira, D., Muñoz, M., Lavandero, S., and Fiedler, J. L. (2014). Serotonin $(5-\mathrm{HT})$ regulates neurite outgrowth through $5-\mathrm{HT}_{1 \mathrm{~A}}$ and $5-\mathrm{HT}_{7}$ receptors in cultured hippocampal neurons. J. Neurosci. Res. 92, 1000-1009. doi: 10.1002/jnr.23390

Ruocco, L. A., Treno, C., Gironi Carnevale, U. A., Arra, C., Boatto, G., Nieddu, M., et al. (2014). Prepuberal stimulation of 5-HT7-R by LP-211 in a rat model of hyper-activity and attention-deficit: permanent effects on attention, brain amino acids and synaptic markers in the fronto-striatal interface. PLoS ONE 9:e83003. doi: 10.1371/journal.pone.0083003

Sałat, K., Podkowa, A., Mogilski, S., Zarêba, P., Kulig, K., Sałat, R., et al. (2015). The effect of GABA transporter 1 (GAT1) inhibitor, tiagabine, on scopolamineinduced memory impairments in mice. Pharmacol. Rep. doi: 10.1016/j.pharep. 2015.04.018

Samarajeewa, A., Goldemann, L., Vasefi, M. S., Ahmed, N., Gondora, N., Khanderia, C., et al. (2014). 5- $\mathrm{HT}_{7}$ receptor activation promotes an increase in TrkB receptor expression and phosphorylation. Front. Behav. Neurosci. 8:391. doi: 10.3389/fnbeh.2014.00391

Saroja, S. R., Kim, E. J., Shanmugasundaram, B., Höger, H., and Lubec, G. (2014). Hippocampal monoamine receptor complex levels linked to spatial memory decline in the aging C57BL/6J. Behav. Brain Res. 264, 1-8. doi: 10.1016/j.bbr.2014.01.042

Sase, S., Stork, O., Lubec, G., and Li, L. (2015). Contextual fear conditioning modulates hippocampal AMPA-, GluN1- and serotonin receptor 5-

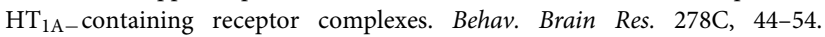
doi: 10.1016/j.bbr.2014.09.035

Saulin, A. I., Savli, M., and Lanzenberger, R. (2012). Serotonin and molecular neuroimaging in humans using PET. Amino Acids 42, 2039-2057. doi: 10.1007/s00726-011-1078-9

Scarr, E., Millan, M. J., Bahn, S., Bertolino, A., Turck, C. W., Kapur, S., et al. (2015). Biomarkers for psychiatry: the journey from fantasy to fact, a report of the 2013 CINP Think Tank. Int. J. Neuropsychopharmacol. doi: 10.1093/ijnp/ pyv042. [Epub ahead of print].

Schmitt, U., and Hiemke, C. (2002). Tiagabine, a gamma-amino-butyric acid transporter inhibitor impairs spatial learning of rats in the Morris water-maze. Behav. Brain Res. 133, 391-394. doi: 10.1016/S0166-4328(02) 00008-6

Segu, L., Lecomte, M. J., Wolff, M., Santamaria, J., Hen, R., Dumuis, A., et al. (2010). Hyperfunction of muscarinic receptor maintains long-term memory in 5- $\mathrm{HT}_{4}$ receptor knock-out mice. PLoS ONE 5:e9529. doi: 10.1371/journal.pone.0009529

Seo, J., and Tsai, L. H. (2014). Neuronal differentiation: $5-\mathrm{HT}_{6} \mathrm{R}$ can do it alone. Nat. Chem. Biol. 10, 488-489. doi: 10.1038/nchembio. 1557

Seyedabadi, M., Fakhfouri, G., Ramezani, V., Mehr, S. E., and Rahimian, R. (2014). The role of serotonin in memory: interactions with neurotransmitters and downstream signaling. Exp. Brain Res. 232, 723-738. doi: 10.1007/s00221-0133818-4

Sheline, Y. I., West, T., Yarasheski, K., Jasielec, M. S., Hettinger, J. C., Tripoli, D. L., et al. (2014b). Reply to comment on "An antidepressant decreases CSF A $\beta$ production in healthy individuals and in transgenic AD mice." Sci. Transl. Med. 6, 268lr4. doi: 10.1126/scitranslmed.3010609

Sheline, Y. I., West, T., Yarasheski, K., Swarm, R., Jasielec, M. S., Fisher, J. R., et al. (2014a). An antidepressant decreases CSF A $\beta$ production in healthy individuals and in transgenic AD mice. Sci. Transl. Med. 6, 236re4. doi: $10.1126 /$ scitranslmed.3008169
Shi, J., Cai, Y., Liu, G., Gong, N., Liu, Z., Xu, T., et al. (2012). Enhanced learning and memory in GAT1 heterozygous mice. Acta Biochim. Biophys. Sin. 44, 359-356. doi: 10.1093/abbs/gms005

Shimizu, S., Mizuguchi, Y., and Ohno, Y. (2013). Improving the treatment of schizophrenia: role of 5-HT receptors in modulating cognitive and extrapyramidal motor functions. CNS Neurol. Disord. Drug Targets 12, 861-869. doi: 10.2174/18715273113129990088

Silverman, J. L., Gastrell, P. T., Karras, M. N., Solomon, J., and Crawley, J. N. (2015). Cognitive abilities on transitive inference using a novel touchscreen technology for mice. Cereb. Cortex 25, 1133-1142. doi: 10.1093/cercor/ bht 293

Söderqvist, S., Bergman Nutley, S., Peyrard-Janvid, M., Matsson, H., Humphreys, K., Kere, J., et al. (2012). Dopamine, working memory, and training induced plasticity: implications for developmental research. Dev. Psychol. 48, 836-843. doi: $10.1037 / \mathrm{a} 0026179$

Solodkin, A., and van Hoesen, G. (1997). "Neuropathology and functional anatomy of Alzheimer's disease," in Pharmacological Treatment of Alzheimer's Disease, eds J. Brioni and M. Decker (New York, NY: Wiley-Liss), 151-177.

Strac, D. S., Muck-Seler, D., and Pivac, N. (2015). Neurotransmitter measures in the cerebrospinal fluid of patients with Alzheimer's disease: a review. Psychiatr. Danub. 27, 14-24.

Stroth, N., Niso, M., Colabufo, N. A., Perrone, R., Svenningsson, P., Lacivita, E., et al. (2015). Arylpiperazine agonists of the Serotonin 5-HT1A receptor preferentially activate cAMP signaling versus. recruitment of $\beta$-Arrestin-2. Bioorganic Med. Chem. doi: 10.1016/j.bmc.2015.05.042

Subramaniyan, S., Hajali, V., Scherf, T., Sase, S. J., Sialana, F. J., Gröger, M., et al. (2015). Hippocampal receptor complexes paralleling LTP reinforcement in the spatial memory holeboard test in the rat. Behav. Brain Res. 283C, 162-174. doi: 10.1016/j.bbr.2015.01.036

Subramaniyan, S., Heo, S., Patil, S., Li, L., Hoger, H., Pollak, A., et al. (2014). A hippocampal nicotinic acetylcholine alpha 7-containing receptor complex is linked to memory retrieval in the multiple-T-maze in C57BL/6j mice. Behav. Brain Res. 270, 137-145. doi: 10.1016/j.bbr.2014.05.012

Sumiyoshi, T., Bubenikova-Valesova, V., Horacek, J., and Bert, B. (2008). Serotonin1A receptors in the pathophysiology of schizophrenia: development of novel cognition-enhancing therapeutics. Adv. Ther. 25, 1037-1056. doi: 10.1007/s12325-008-0102-2

Sun, M. K., Nelson, T. J., and Alkon, D. L. (2015). Towards universal therapeutics for memory disorders. Trends Pharmacol. Sci. 36, 384-394. doi: 10.1016/j.tips. 2015.04.004

Suzuki, H. I., and Lucas, L. R. (2015). Neurochemical correlates of accumbal dopamine D2 and amygdaloid 5-HT 1B receptor densities on observational learning of aggression. Cogn. Affect. Behav. Neurosci. 15, 460-474. doi: 10.3758/ s13415-015-0337-8

Tajiri, M., Hayata-Takano, A., Seiriki, K., Ogata, K., Hazama, K., Shintani, N., et al. (2012). Serotonin 5- $\mathrm{HT}_{7}$ receptor blockade reverses behavioral abnormalities in PACAP-deficient mice and receptor activation promotes neurite extension in primary embryonic hippocampal neurons: therapeutic implications for psychiatric disorders. J. Mol. Neurosci. 48, 473-481. doi: 10.1007/s12031-0129861-y

Talpos, J. C., Aerts, N., Fellini, L., and Steckler, T. (2014). A touch-screen based paired-associates learning (PAL) task for the rat may provide a translatable pharmacological model of human cognitive impairment. Pharmacol. Biochem. Behav. 122, 97-106. doi: 10.1016/j.pbb.2014.03.014

Talpos, J., and Shoaib, M. (2015). Executive function. Handb. Exp. Pharmacol. 228, 191-213. doi: 10.1007/978-3-319-16522-6_6

Tellez, R., Gómez-Viquez, L., Liy-Salmeron, G., and Meneses, A. (2012b). GABA, glutamate, dopamine and serotonin transporters expression on forgetting. Neurobiol. Learn. Mem. 98, 66-77. doi: 10.1016/j.nlm.2012.05.001

Tellez, R., Gómez-Víquez, L., and Meneses, A. (2012a). GABA, glutamate, dopamine and serotonin transporters expression on memory formation and amnesia. Neurobiol. Learn. Mem. 97, 189-201. doi: 10.1016/j.nlm.2011. 12.002

Tellez, R., Rocha, L., Castillo, C., and Meneses, A. (2010). Autoradiographic study of serotonin transporter during memory formation. Behav. Brain Res. 12, 12-26. doi: 10.1016/j.bbr.2010.03.015

Thomasius, R., Zapletalova, P., Petersen, K., Buchert, R., Andresen, B., Wartberg, L., et al. (2006). Mood, cognition and serotonin transporter availability in 
current and former ecstasy (MDMA) users: the longitudinal perspective. J. Psychopharmacol. 20, 211-225. doi: 10.1177/0269881106059486

Thompson, A. J. (2013). Recent developments in $5-\mathrm{HT}_{3}$ receptor pharmacology. Trends Pharmacol. Sci. 34, 100-109. doi: 10.1016/j.tips.2012.12.002

Thur, K. E., Nelson, A. J., and Cassaday, H. J. (2014). Ro 04-6790-induced cognitive enhancement: no effect in trace conditioning and novel object recognition procedures in adult male Wistar rats. Pharmacol. Biochem. Behav. 127, 42-48. doi: 10.1016/j.pbb.2014.10.006

Tomie, A., Di Poce, J., Aguado, A., Janes, A., Benjamin, D., and Pohorecky, L. (2003). Effects of autoshaping procedures on ${ }^{3} \mathrm{H}-8$-OH-DPAT-labeled 5- $\mathrm{HT}_{1 a}$ binding and ${ }^{125} \mathrm{I}-\mathrm{LSD}$-labeled $5-\mathrm{HT}_{2 a}$ binding in rat brain. Brain Res. 975, 167-178. doi: 10.1016/S0006-8993(03)02631-3

Tomie, A., Lincks, M., Nadarajah, S. D., Pohorecky, L. A., and Yu, L. (2012). Pairings of lever and food induce Pavlovian conditioned approach of sign-tracking and goal-tracking in C57BL/6 mice. Behav. Brain Res. 226, 571-578. doi: 10.1016/j.bbr.2011.10.021

van Goethem, N. P., Schreiber, R., Newman-Tancredi, A., Varney, M., and Prickaerts, J. (2015). Divergent effects of the "biased," 5-HT1A receptor agonists F15599 and F13714 in a novel object pattern separation task. Br. J. Pharmacol. 172, 2532-2543. doi: 10.1111/bph.13071

Vanover, K. E., Harvey, S. C., Son, T., Bradley, S. R., Kold, H., Makhay, M., et al. (2004). Pharmacological characterization of AC-90179 [2-(4-methoxyphenyl) -N-(4-methyl-benzyl)-N-(1-methyl-piperidin-4-yl)-acetamide hydrochloride]: a selective serotonin 2A receptor inverse agonist. J. Pharmacol. Exp. Ther. 310, 943-951. doi: 10.1124/jpet.104.066688

Vardy, E., and Kenakin, T. (2014). The tail wags the dog: possible mechanism for reverse allosteric control of ligand-activated channels. Br. J. Pharmacol. 171, 1614-1616. doi: 10.1111/bph.12550

Varrone, A., Svenningsson, P., Marklund, P., Fatouros-Bergman, H., Forsberg, A., Halldin, C., et al. (2015). 5-HT1B receptor imaging and cognition: a positron emission tomography study in control subjects and Parkinson's disease patients. Synapse 69, 365-374. doi: 10.1002/syn.21823

Vimala, P. V., Bhutada, P. S., and Patel, F. R. (2014). Therapeutic potential of agomelatine in epilepsy and epileptic complications. Med. Hypotheses 82, 105-110. doi: 10.1016/j.mehy.2013.11.017

Volpicelli, F., Speranza, L., di Porzio, U., Crispino, M., and Perrone-Capano, C. (2014). The serotonin receptor 7 and the structural plasticity of brain circuits. Front. Behav. Neurosci. 8:318. doi: 10.3389/fnbeh.2014.00318

Waeber, C., Sebben, M., Bockaert, J., and Dumuis, A. (1996). Regional distribution and ontogeny of 5- $\mathrm{HT}_{4}$ binding sites in rat brain. Behav. Brain Res. 73, 259-262. doi: 10.1016/0166-4328(96)00108-8

Wagner, A., and Davachi, L. (2001). Cognitive neuroscience: forgetting of things past. Curr. Biol. 11, R964-R967. doi: 10.1016/S0960-9822(01)00575-9

Walker, E. A., and Foley, J. J. (2010). Acquisition session length modulates consolidation effects produced by $5-\mathrm{HT}_{2 \mathrm{C}}$ ligands in a mouse autoshaping-operant procedure. Behav. Pharmacol. 21, 83-89. doi: 10.1097/FBP.0b013e328337bde7

Walker, E. A., Foley, J. J., Clark-Vetri, R., and Raffa, R. B. (2011). Effects of repeated administration of chemotherapeutic agent tamoxifen, methotrexate, and 5fluorouracil on the acquisition and retention of a learned response in mice. Psychopharmacology (Berl). 217, 539-548. doi: 10.1007/s00213-011-2310-8

Wallace, A., Pehrson, A. L., Sánchez, C., and Morilak, D. A. (2014). Vortioxetine restores reversal learning impaired by 5-HT depletion or chronic intermittent cold stress in rats. Int. J. Neuropsychopharmacol. 17, 1695-1706. doi: $10.1017 /$ S1461145714000571

Wasserman, E. A. (1981). "Response evocation in autoshaping: contribution of cognitive and comparative_evolutionary analysis to an understanding of directed action," in Autoshaping and Conditioning Theory, eds C. M. Locurto, H. S. Terrace, and J. Gibbon (New York, NY: Academic Press), 21-54.

Waters, K. A., Stean, T. O., Hammond, B., Virley, D. J., Upton, N., Kew, J. N., et al. (2012). Effects of the selective $5-\mathrm{HT}_{7}$ receptor antagonist SB-269970 in animal models of psychosis and cognition. Behav. Brain Res. 228, 211-218. doi: 10.1016/j.bbr.2011.12.009

Weber, T., Vogt, M. A., Gartside, S. E., Berger, S. M., Lujan, R., Lau, T., et al. (2015). Adult AMPA GLUA1 receptor subunit loss in 5-HT neurons results in a specific anxiety-phenotype with evidence for dysregulation of 5-HT neuronal activity. Neuropsychopharmacology 40, 1471-1484. doi: 10.1038/npp.2014.332

Wellman, C. L., Izquierdo, A., Garrett, J. E., Martin, K. P., Carroll, J., Millstein, R., et al. (2007). Impaired stress-coping and fear extinction and abnormal corticolimbic morphology in serotonin transporter knock-out mice. J. Neurosci. 27, 684-691. doi: 10.1523/JNEUROSCI.4595-06.2007

Westrich, L., Haddjeri, N., Dkhissi-Benyahya, O., and Sanchez, C. (2015). Involvement of $5-\mathrm{HT}_{7}$ receptors in vortioxetine's modulation of circadian rhythms and episodic memory in rodents. Neuropharmacology 89, 382-390. doi: 10.1016/j.neuropharm.2014.10.015

White, N. M., and McDonald, R. J. (2002). Multiple parallel memory systems in the brain of the rat. Neurobiol. Learn. Mem. 77, 125-184.

Wilcove, W. G., and Miller, J. C. (1974). CS-UCS presentations and a lever: human autoshaping. J. Exp. Psychol. 103, 868-877. doi: 10.1037/h0037388

Wilkinson, D., Windfeld, K., and Colding-Jørgensen, E. (2014). Safety and efficacy of idalopirdine, a $5-\mathrm{HT}_{6}$ receptor antagonist, in patients with moderate Alzheimer's disease (LADDER): a randomised, double-blind, placebocontrolled phase 2 trial. Lancet Neurol. 13, 1092-1099. doi: 10.1016/S14744422(14)70198-X

Wixted, J. T. (2004). The psychology and neuroscience of forgetting. Annu. Rev. Psychol. 55, 235-269. doi: 10.1146/annurev.psych.55.090902.141555

Woehrle, N. S., Klenotich, S. J., Jamnia, N., Ho, E. V., and Dulawa, S. C. (2013). Effects of chronic fluoxetine treatment on serotonin $1 \mathrm{~B}$ receptor-induced deficits in delayed alternation. Psychopharmacology (Berl). 227, 545-551. doi: 10.1007/s00213-013-2985-0

Wolf, J. E., Urbano, C. M., Ruprecht, C. M., and Leising, K. J. (2014). Need to train your rat? There is an App for that: a touchscreen behavioral evaluation system. Behav. Res. Methods 46, 206-214. doi: 10.3758/s13428-013-0366-6

Wolff, M., Savova, M., Malleret, G., Hen, R., Segu, L., and Buhot, M. C. (2003). Serotonin 1B knockout mice exhibit a task-dependent selective learning facilitation. Neurosci. Lett. 338, 1-4. doi: 10.1016/S0304-3940(02)01339-3

Woods, S., Clarke, N., Layfield, R., and Fone, K. (2012). 5- $\mathrm{HT}_{6}$ receptor agonists and antagonists enhance learning and memory in a conditioned emotion response paradigm by modulation of cholinergic and glutamatergic mechanisms. Br. J. Pharmacol. 167, 436-449. doi: $10.1111 / \mathrm{j} .1476-5381.2012 .02022 . \mathrm{x}$

Yamazaki, M., Harada, K., Yamamoto, N., Yarimizu, J., Okabe, M., Shimada, T., et al. (2014). ASP5736, a novel 5- $\mathrm{HT}_{5 \mathrm{~A}}$ receptor antagonist, ameliorates positive symptoms and cognitive impairment in animal models of schizophrenia. Eur. Neuropsychopharmacol. 24, 1698-1708. doi: 10.1016/j.euroneuro.2014. 07.009

Yamazaki, M., Okabe, M., Yamamoto, N., Yarimizu, J., and Harada, K. (2015). Novel $5-\mathrm{HT}_{5 \mathrm{~A}}$ receptor antagonists ameliorate scopolamine-induced working memory deficit in mice and reference memory impairment in aged rats. J. Pharmacol. Sci. 127, 362-369. doi: 10.1016/j.jphs.2015.02.006

Yang, P., Cai, G., Cai, Y., Fei, J., and Liu, G. (2013). Gamma aminobutyric acid transporter subtype 1 gene knockout mice: a new model for attention deficit/hyperactivity disorder. Acta Biochim. Biophys. Sin. 45, 578-585. doi: 10.1093/abbs/gmt043

Yoshimi, N., Fujita, Y., Ohgi, Y., Futamura, T., Kikuchi, T., and Hashimoto, K. (2014). Effects of brexpiprazole, a novel serotonin-dopamine activity modulator, on phencyclidine-induced cognitive deficits in mice: a role for serotonin $5-\mathrm{HT}_{1 \mathrm{~A}}$ receptors. Pharmacol. Biochem. Behav. 124, 245-249. doi: 10.1016/j.pbb.2014.06.008

Zaldivar, A., and Krichmar, J. L. (2013). Interactions between the neuromodulatory systems and the amygdala: exploratory survey using the allen mouse brain atlas. Brain Struct. Funct. 218, 1513-1530. doi: 10.1007/s00429-0120473-7

Zilles, K., Bacha-Trams, M., Palomero-Gallagher, N., Amunts, K., and Friederici, A. D. (2015). Common molecular basis of the sentence comprehension network revealed by neurotransmitter receptor fingerprints. Cortex 63, 79-89. doi: 10.1016/j.cortex.2014.07.007

Conflict of Interest Statement: The author declares that the research was conducted in the absence of any commercial or financial relationships that could be construed as a potential conflict of interest.

Copyright $(2015$ Meneses. This is an open-access article distributed under the terms of the Creative Commons Attribution License (CC BY). The use, distribution or reproduction in other forums is permitted, provided the original author(s) or licensor are credited and that the original publication in this journal is cited, in accordance with accepted academic practice. No use, distribution or reproduction is permitted which does not comply with these terms. 